Z tajnych archiwów radzieckich (9)

MICHA£ GNATOWSKI (Białystok)

\title{
RADZIECKIE DOKUMENTY O PRZYGOTOWANIACH DO WYBORÓW DO ZGROMADZENIA LUDOWEGO ZACHODNIEJ BIAEORUSI ORAZ SPRAWOZDANIA Z PRZEBIEGU KAMPANII WYBORCZEJ W WOJEWÓDZTWACH I POWIATACH. CZĘŚĆ II ${ }^{1}$
}

\section{Dokument 11}

1939 październik 26, Grajewo, - Raport z kampanii wyborczej do Zgromadzenia Ludowego Zachodniej Biatorusi w powiecie szczuczyńskim.

Cекретно. $^{\mathrm{a}}$

ШК КП(б)Б СНК БССР, ОБКОМУ КП(б)Б И ОБЛ. ИСПОЛКОМУ Белостокской области.

Докла.цная записка об итогах выборов Депутатов в Белорусское Народное Собрание.

По Щучинскому уез.ду.

1.

Некоторые данные об экономическом и политическом состоянии уезда.

По официальным статистическим данным 1939 г. по Щучинскому уезду насчитывается - 74090 чел. населения из них: поляков -66090 , евреев - 7912, белоруссов - 1, других национальностей -81 .

1 Część I opublikowana została w tomie XII „Studiów Podlaskich” 2002, s. 303-378. 
Население района занимается приимущественно земледелием. Из промынленных предприятий в районе имеется только несколько винокуренных заводов и 1 мануфактурно-резиновая фабрика.

Всего в уез.це насчитывается 9522 хозяйства. По земле обеспеченности они распределяются следующим образом:

$$
\begin{array}{lll}
\text { от } 00 & \text { до } 2 \text {-х га. } & =1676 \text { хоз-в. } \\
\text { от } 2-x & \text { до } 5 \text { га. } & =267-"- \\
\text { от } 5 & \text { до } 20 \text { га. } & =4654-"- \\
\text { от } 20 & \text { до } 50 \text { га. } & =749-"- \\
\text { от } 50 & \text { до } 100 \text { га. } & =131-"- \\
\text { от } 100 \text { и выне га. } & =45-"-(\text { помещечьих }) \text {. }
\end{array}
$$

Этим сорока пяти помещечьим хозяйствам принадлежить свыпе сорока процентов. всех земельных угодий в уез,де. Приимущественное же больпинство хозяйств имеюших до 5 га. земли были безкаровными или безлошадными, не имели своего инвентаря и вечно находились в кабале у помещиков и кулаков.

Официально зарегистрированных безработных по городам уезда насчитывалось свыпе 800 чел., несчитая тех, которые работали по несколько дней в неделю и женшин, которые также статистикой о безработице очеви,цно не регистрировались.

В уезде имелось 73 школы, в которых по данным польской статистики обучалось 13640 чел. 1470 детей школьного возраста по тем же данным не охваченных школой.

В районе имелось около 50 разных политических антисоветских партий и организаций, насчитывающих несколько десятков тысяч своих членов. Ячейки этих организаций имелись не только по городским пунктам но и на деревне и даже среди женщин. В ряде случаев втянутыми в эти организации оказались отдельные бедняки деревни и ,даже рабочие городов и местечек.

\section{Данные об ходе по.цготовки к выборам.}

Всего в уезде было создано 15 изберательных округов и 107 изберательных участков. В окружных и участковых изберательных комиссиях работало 854 чел,, в том числе местного населения 732 чел. из 854 чел. членов окружных и участковых изберательных комиссий по национальности было: поляков 589 чел., евреев - 145 чел., великорусов 111 , и белоруссов - 11 чел. 
Кроме того для прове,дения агитационно массовой работы среди населения в качестве пропагандистов было привлечено 1120 чел. из коих 750 чел. из состава местного населения. Вся эта армия агитаторов систематически вела агитационно массовую работу на изберательных участках.

В цень самих выборов командованием воинских частей дополнительно было брошено на участки для проведения агитационной раб̆оты около 1,5 тыс. чел.

Этими силами во всех населенных пунктах уез,да было проведено 900 собраний. 21.10.39 г. на кануне выборов по всем участкам были проведены пред изберательные митинги - всего таких митингов поо уез,ду проведено 208, кроме того проведено 4435 групповых бесед и 6200 семейств охвачены индивидуальными беседами.

Поголовное болыпинство тру,дяпихся масс населения уезда приняло активное участие во всей изберательной компании. На собраниях и митингах представители тру,дяцихся масс выступали с горячими речами, в которых благодарили Советское Правительство, Красную Армию за освобождение народов Запа,дной Белоруссии и Украины от польско-помецечьего гнета и иноземного ига Германского империализма, требовали установления Советской Власти в Запа,дной Белоруссии, присоединения Западной Белоруссии к БССР, национализацию банков и крупной промышленности, конфис кацию помецечьих имений.

\section{Ход выборов в народное собрание.}

Учет хода голосования в разрезе изберательных участков и округов велся через каждые два часа и поступал ввиде сводок во временное управление уезда. Это давало возможность быстро реагировать на прорывы на отдельных изберательных участках и устранять недостатки в работе окружных и участковых изберательных комиссий.

На ряде участков отстапюии округов $22 / \mathrm{X}$ в четыре пять часов ,дня голосовавших было не более $8-10 \%$ общего числа изберателей. На эти участки были брошены дополнительные силы в составе 15 чел. мобилизованных МК КП(б)Б и 300 чел. из воинских частей. Все это в значительной степени улучшило положение дел в отстагщих округах. Итоги голосования по всему уезду в разрезе каждого округа характеризуются следуюшцими данными: 


\begin{tabular}{|c|c|c|c|c|c|c|}
\hline \multirow[t]{2}{*}{$\begin{array}{c}\text { № № } \\
\text { округов }\end{array}$} & \multirow[t]{2}{*}{ название округа } & \multirow[t]{2}{*}{$\begin{array}{c}\text { количество } \\
\text { избирателей } \\
\text { по списку }\end{array}$} & \multicolumn{2}{|c|}{$\begin{array}{c}\text { количество } \\
\text { избирателей } \\
\text { голосовавших }\end{array}$} & \multicolumn{2}{|c|}{$\begin{array}{c}\text { голосовало } \\
\text { за } \\
\text { кандидатов }\end{array}$} \\
\hline & & & число & $\%$ & число & $\%$ \\
\hline 211. & Граевский - город & 2544 & 2544 & 100 & 2104 & 82,7 \\
\hline 212. & _" & 1960 & 1951 & 99,5 & 1796 & 92,0 \\
\hline 213. & Богушевский с/сел. & 2330 & 2080 & 89,2 & 1132 & 54,4 \\
\hline 214. & Пшеходовский с/с. & 2235 & 1989 & 88,9 & 1501 & 75,4 \\
\hline 215. & Прусский сельский & 2600 & 2578 & 99,1 & 1647 & 63,8 \\
\hline 216. & Белдовский -" & 3031 & 3017 & 99,5 & 2032 & 67,3 \\
\hline 217. & Белашовский -" - & 2711 & 2016 & 74,4 & 1190 & 59,0 \\
\hline 218. & Радзиловский -" - & 2968 & 2153 & 72,5 & 1928 & 89,5 \\
\hline 219. & Шученский с/сел. & 2875 & 2029 & 70,5 & 1180 & 58,1 \\
\hline 220. & Шученский город & 2594 & 2460 & 94,8 & 2275 & 92,4 \\
\hline 222. & Вонсошский -" - & 1789 & 1374 & 76,8 & 1081 & 78,6 \\
\hline 223. & Ляховский - - - & 2580 & 2171 & 84,1 & 1483 & 68,3 \\
\hline 224. & Лавский & 1877 & 1590 & 84,7 & 1029 & 64,7 \\
\hline 225. & Райгоро.цский -" - & 2042 & 2019 & 98,8 & 1825 & 90,3 \\
\hline 221. & Грабовский сельский & 2295 & 1882 & 82,0 & 1362 & 73,3 \\
\hline \multicolumn{2}{|c|}{ ВСЕГО по уезду } & 36431 & 31853 & 87,4 & 23565 & 73,9 \\
\hline
\end{tabular}

Избранного всего по уезду 15 депутатов из них по национальности: поляков 13 , евреев 2 , по полу мужчин 13 , женцин 2 , по национальному положению рабочих - 7 , батраков 3 , крестьян середняков 3 , учителей 2 .

\section{Классово враждебная деятельность антисоветских партий.}

Антисоветские партии и остатки польско-помещечье буржуазной контреволюции еще в перио.д по.дготовки к выборам нередко выступали на собраниях контреволюционными решениями. На о.дном из собраний 17 октября пред. собрания Доновский, член партии $\mathrm{O} 3 \mathrm{OH}$, бывІпий волостной старіпина выступил с контреволюционной речью призываюпей не голосовать за резолюцию предложенную коммунистами требующию установлению советской власти в Запа,дной Белоруссии, присоединения Западной Белоруссии к БССР, национализацию банков, крупной промыпленности и. т. д. и заявил, что мы будем голосовать за единство Полыни и буржуазного управления. 
Radzieckie dokumenty o przygotowaniach d• wyborów do Zgromadzenia Ludowege... 297

Зарегисгрировано ряд случаев проведения нелегальных собраний, на которых обсуждались вогросы бойкота выборов.

Особенную активность проявили все контреволюционные силы в последние дни на кануне выборов и в день самих выборов. 20 октября 1939 г. в г. Граево на двух изберательных участках были залиты чернилами изберательные плакаты, вывепенные на изберательных участках. 3.десь же и в ряде других пунктов распростронялись пи санные отруки контреволюционные лозунги „Поляки не голосуйте за евреев и коммунистов", „Голосуйте за Гитлера и присоединение к Германии", „Долой евреев и коммунистов", „Крестьлне не приветствуйте коммунистов" и др.

Подобного характера лозунги оказывались и в урнах избератејьных участков.

Под влиянием әтой работы контреволюционных пгартий на отцельных участках со стороны зажиточной части населения были упорные попытки байкотировать выборы. Так из 16 хозяйств деревни Курки только две семьи батраков явились на голосование, a 14 остальных имеюших по 30-70 га земли (осадники на границе с Пруссией) весь день пробыли в костеле а вечером ушли из дому. Анологичное положение былю на ряде участков Белошовского изберательного округа. Там из трех сот чел. изберателей деревень Заборов-Бегенище и Сулево-Ковнаты голосовало только 38 чел.

Многне из остальных ушли даже с детьми в близ лежайший лес и были там до поздней ночи.

Во преки всей этой контреволюционной ,деятельности антисоветских партий основная масса трудлцихся уезда приняла активное участие в выборах и провела по всем участкам своих депутатов в Белорусское Народное Собрание.

\section{Обшие ВЫВОцЫ:}

1. Основная масса трудлпихся населения с болыпой политической активностью приняло участие в проведении всей изберательной компании не смотря на усизенную работу антисоветских партий іго бойкоту к выборам.

2. За время проведения выборной компании, в борьбе за проведение депутатов трудящихся в наро,дное собрание выявлено до 700 чел. местного актива проимущественно из деревенской бе,дноты и батраков, а в горо,дах из числа рабочих и еврейской бедноты.

3. Огромную трудность в работе во время выборов представляло 
не знание товарицами мобилизованными IIK KII(б)Б, а также военными посланными на эту работу национального польского языка; так как поголовное болыпинство населения уезда не знает русского языка, а из молодежи почти ни кто. Это затрудняло обıцение с народом и агитация была не віолне доходчивой и слабо воспринималась населением. Поэтому считаю необходимо в дальнейшем посылать на работу в этот уезд людей знаюоцих польский язык.

IІРЕДСЕДАТЕЈЬ ВРЕМЕННОГО УІІРАВЛЕНИЯ ЩУЧИНСКОГО УЕЗДА (podpis) (ШEPCTHEB)

IIАРТОРГ УЕЗДА (podpis) (ГРАКОВ)

26.10 .39 г.

Oryginal, maszynopis.

Źródło: PAOSOG w Grodnie, zesp. 6195, spr. 1, t. 234, k. 33-35.

a Podkreślenie i wielkie litery oryginału.

\section{Dokument 12}

1939 październik po 26, Biatystok, - Sprawozdanie Topaz-aktywistki z Mińska z przygotowan i przebiegu wyborów do Zgromadzenia Ludowego Zachodniej Biatorusi w Biatymstoku i powtórnych wyborach w Sokotach.

\section{ОТДЕЛУ IIPOIIАГАНДЫ И АГИТАІІИИ

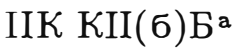

\section{ДОКЛАДНАЯ ЗАІІИСКА}

Я была командирована сроком на 20 дней в Западную Белоруссию, г. Белосток для пропагандистско-агитационной работы по выборам депутатов в Народное Собрание: При прибытии туда товариц Игаев меня направил уполномоченным в 14-й избирательный округ. 


\section{Характеристика расположения избирательного округа}

14 избирательный округ размещен на территории центра гор. Белостока и охватывает улицы:

1. Маршала Пилсудского.

2. Рынок Костюони.

3. Суранская.

4. Минская

и прилегаюших к ним улиц. Всего избирательных участков было 4: I-й, II-й, III-й и IV-й. Население этого избирательного округа преимушественно крупная еврейская буржуазия. Часть мелких торговцев и кустарей, которые имегот от 2-х до 5 рабочих. Рабочая прослойка в этом округе почти отсутствовала.

$11 / \mathrm{X}-39$ г. Я провела совешание председателей и секретарей участковых избирательных комиссий. На этом совеццании был пос'тавлен вопрос о цели и задачах предстоялцих выборов в Народное Собрание. Второе - это тпцательный подбор агитаторов по участкам. Там же на совешании мы их распределили так, что каљждый aгитатор имел в среднем по 5 домов с избирателями, с которыми они проводили систематическую работу.

$12 / \mathrm{X}-39$ г. Совешание актива всего 14 избирательного округа.

Вопросы:

1. Что такое Советская в ласть.

2. Информация с мест председателей участковых комиссий о ходе составления списков избирателей, и агитационно-массовой работы.

Локлалывали товариши: Хайот, Лубницкий, Берников, Заблудовский, Сенин, Хмельник и .др. Информации былик конкретными. Товаришии заверилю, что они постараются полностью выполнить задания, возложенные на них.

13/X-39 г. Собрание пाкольников всего избирательного округа доо 14 лет.

Была проведена беседа.

1. Сталинская Конституция. О праве на образование в СССР.

2. За,дача пшольников в предстояних выборах.

Меня исключительно радовали энтузиазм, приголнятое настроение школьников. Ликуюшая радость. Казалось, что все вокруг смеется вместе со звонким смехом детворы. В заключение они пели все напи советские песни „По военной дороге” , „Катюшу” , „Краснофлотскую", „Все выне” и др. 
14/X-39 г. Общее собрание избирателей 4-го участка 14 избирательного округа с вопросами: 1) О цели и задачах выборов.

2) b Внутренние причины распада польского государства.

Выступили: тов. Хайот - рабочий строитель. Он указал: „Двадцать лет нашша жизнь была покрыта черным покрывалом. Польская пІляхта нас варварски угнетала. Мы не могли свободно дыпать. Тюрьмы и концентрационные лагери были заполнены нашими братьями и сестрами. Вместо хлеба и светлых квартир мы имели безработицу и казематы тюрем. О,днако мы: никогда надежды не теряли. Мы знали, что в нашей борьбе против пляхетской нечисти мы не одни, что нам напи братья помогут. И вот настал для нас радостный ликуюпций день. Взошло чистое светлое лучезарное солнце 17 сентября, когда наш Великий Сталин, советское п-во, Родная Красная Армия подали нам свою могучую руку братской помоци. Она, Красная Армия, вырыла тени-столбы, отодвинула их дальше на Запад. Эти столбы, которые нас искусственно разделялли двадцать лет и делили на два лагеря. Но мысленно мы всегда были с напиими братьями и сестрами Советской Белоруссии. Красная Армия, овеянная леген.дарной славой, которую мы ждали, припла к нам. Когда она к нам приплас, старики, женшины, дети прямо вскрикивали. Это не Армия, это Ангела (общий смех)... Дети бросались к ним на шею крепко обхватывали их. Красноармейіы их тепло обнимали, обогревали их и приласкали. Население от радости плакало. Их забрасывали цветами, яблоками". В заключение Хайот сказал: „От чистого сердца с люобовью, торжественно празднично, с большой радостью мы должны как один придти $22 / \mathrm{X}$ к избирательным урнамя и отдать свои голоса, за нашу избранницу, за дочь нашего народа, которая будет депутатом в Народное Собрание от нас и скажет от имени нашего народа: 1. Что мы требуем объявление Советской власти на. территории Западной Белоруссии. 2. Мы хотим воссоединиться с Сов. Белоруссией и войти в болыпую семью народов СССР. 3. Чтобы избавиться навеки от ницеты эксплуатации и безработицы, мы требуем конфискации помегцичьих и монастырских земель. 4. Мы требуем национализации банков и кругной промынленности".

Речь товарища Хайота неоднократно прерывалась возгласами „Да здравствует Красная Армия!", „Да здравствует нап Великий Сталин". С аналогичной речью на еврейском языке выступил народный учитель города Белостока тов. Заблудовский. Речь то- 
Radzieckie dokumenty a przygotowaniach do wyborów do Zgromadzenia Ludowego... 301

вариша Заблудовского была яркая, полна красочности, насыцена живыми примерами по поводу дикости, варварства со стороны пөльской шляхты, котораял со звериной ненавистью разжигала национальную рознь в Западной Белоруссии. В заключение он сказал „Не бывать здесь болыпе польским панам. Кануло навеки национальное угнетение. Ла здравствует дружба народов". В заключение мы спели на еврейском языке Интернационал.

$15 /$ X-39 г. Обцее собрание 1 избирательного округа.

1) О за,дачах выборов.

2) Национальньй вогрос.

По -национальному вопросу выступил тов. Хмельник, который указывал, что в Запа,дной Белоруссии и Зап. Украине насчитывалось разных контрреволю口ионных партий до 120. Бунд, ППС, Ундеки, правые сионисты, левые сионисты и др. Все они были на изнанку партиями фашиистскми. Эти контрреволюлионные партии старались отравить сознание трудлцихся в своих контрреволюционных целях, они направляли о,дну нацию на другую. В конечном итоге они были хоропими прислужниками своих хозяев. Между собой руководители этих контрреволюционных партий дружили. Капитулко, рук. ППС, всегда вместе пил чай с руководитеэем Бунда Фейгиным. В своих контррев. целях они всегда находили обцций язык. В заключение Хмельник сказал: „Мы все, как один, долэкны разоблачать эти контрреволюлионные партии. Оздоровить сознание трудяцихся. Крегить интернациональную связь". Он призывает: ,Трудяциеся белорусы, подайте руку братской помоци трудяпимся евреям и, наоборот, трудяциеся поляки, по,дайте братскую руку трудящимся евреям и белорусам". Возгласы с мест: „Да здравствует дружба народов!", "Лолой национальную рознь!", "Лолой Iпльлетскую нечисть". Собрание заканчивается пением Интернационала на всех языках.

16/X-39 г. Общее собрание рабочих заводов, фабрик, живуцих на территории 14 избирательного округа.

1) Пре,дстояпце выборы в Народные Собрания Запа,дной Белоруссии.

Сталинская Конституция - IIраво на тру,д.

На,до отметить исключительный подъем масс собравіпихся. Исклюяительная любовь к Краснøй Армии, к ее руководителю тов. Ворошилову. Любовь к вождю народюв тов. Сталину. $K$ трибуне залы подошла работница тов. Каглан и начала дрожашим голосом 
говорить. „Товарици, - сказала она, -- я это слово за двадцать лет впервые произношу. Я произношу его с великой радостью и гордостью. До 17 сентября мы с презрением и ненавистью говорили „пан, проше пану”. Как дико это сейчас мне звучит. Я не оратор, но скажу только одно. Мне сейчас 43 года, я знаю двадцать лет капиталистической варварской эксплуатации ткачихи. Но сейчас, именно сейчас, я новорожденный младенец. Кругом нас здесь наши товарици красноармейцы, коммунисты, нам родные, близкие напи братья, товарици за воссоединение с Белоруссией Советской, за советскую власть. Я болыпе не могу говорить, мое сердце плачет от радости. Мы свободны. О чем мечтали двадцать лет. Мы хозяева освобожденной земли".

$17 / \mathrm{X}-39$ г. Объединенный митинг всех участников всего 14 избират. округа в кино «Свят».

1. Встреча с кандидатом в депутаты Народного Собрания Шегельницкой Фаней Абрамовной.

Митинг этот прошел с исключительным подъемом. Шламенные речи. Возгласы с мест: „За Шегельницкую”, „За Советскую власть”, „Нех жые Чырвона Армия!”, „Нех жые товажыш Сталин!” Митинг закончился пением Интернационала и просмотром кинофильма «Случай на полустанке».

18/X-39 г. Общее собрание молодежи всего округа с вопросом:

1) Жизнь молодежи в СССР под солнцем Сталинской Конституции.

На трибуну взошла бежкенка гор. Варшавы молодая комсомолка Польпи Левит Э. Она рассказала о той беспросветной жкизни, гнете, который ислытывал молодой челювек в панской «цивилизованной» Польше. Она сама всю жизнь мечтала учиться в Университете. Но не тут-то было. Шотому, что она еврейка, ее никуда не принимали. В Вузах принимали сыновей, дочерей купцов, фабрикантов и помециков. На 1400 мест в Варшавском агроинституте всех евреев приняли 60 человек. И то по этим варварским законам им отводилась левая сторона, и учиться они должны были, стоя. „Я, говорит она, - рассказываю тысячную долю издевательств, описать полностью проделки шляхетской нечисти над молюдежью невозможно. Посмотрите, товарици, как молюдежь длинными вереницами тянется, бежит из Варшавы, Вильно. Бегут именно на территорию освобожденной земли, где они знают, что Великий кузнец счастья тов. Сталин кует счастье всему народу земли Советской, 
Radzieckie dokumenty o przygotowaniach do wyborów do Zgromadzenia Ludowego... 303

в том числе и молодежи, Молодежь бежит туда, где она будет жить счастливо радостно, будет согрета лучами сталинской заботы. Я заканчиваю, но не ошибусь, если выражу свое мнение от имени всего нашего собрания молодеж". Заверим, что те задачи по выборам, которые будут возложены на нас, мы с честью выполним. Все как один от,цадим свои голоса за нашу Фаню".

19/X-39 г. Митинг всего избирательного округа в кино «IIaн». Зала была переполнена. Мы не могли разместить наших избирателей. На этом митинге была встреча избирателей с кандидатом в .депутаты Народного собрания тов. Щегельницкой. Щегельницкая рассказала своим избирателям свою автобиографию. Уроженка она гор.Белостока, дочь кустаря портного. Сама она портниха. Будучи пюкольницей, с 12 летнего возраста она ужке принимала участие в ученических организациях. Особенное участие в организации этих ученических организаций принимал учитель т. Мошевицкий, ныне депутат Народного Собрания. Вступила в комсомол Зап. Бел. В 1927 г. вступила в партию, после чего была командирована Коминтерном в Комвуз нац. Меньп. Запада в Москве. По окончании комвуза ее послали на партийную работу в гор. Витебск, там она работалга секретарем парткома ф-ки «Двина». Вывела свою фабрику к 1-му маю 1932 г. на передовую линию по выполнению промфинілана. Затем Фаня обращаетсл в президиум 14 партсъезда с просьбой разрешить ей выехать для подлольной работы в Запа,цную Белоруссиғо. Президиум удовлетворяет ее просьбу. Шегельницкая уезжает туда, там она назначается парторгом Виленского воеводства. Но провокатор, спустя полтора месяца, выдает ее. Она была заточена фашистскими палачами в тюрьму, где просидела семь лет, испытывая на себе все ужасы фашистских издевательств. Она еще болыне закалила себя в борьбе против панского ига. Ее освободила наша героическая доблестная Красная Армия. „Щегельницкая - наша. Она верная дочь трудового народа, - говорит тов. Бляхова, - мы все как один подадим за нее свои голоса. Она выполнит наш наказ и скажет Народному Собранию - За Советскую власть, за воссоединение с БССР и вхождение в СССР, болыпую семью народов, за конфискациғо крупных помецичьих и монастырских земель, за национализацию банков и крупной промышленности. Все как один за IІегельницкую, за Фаню, - заканчивает тов. Бляхова, - Да здравствует вождь всех трудящихся Великий Сталин! Сталину ура!"

Митинг закончился пением Интернационала на всех языках 
и просмотром кинофијьма „Ленин в 1918 г.”.

20/X-39 г. Общее собрание женщин всего округа в театре «ПаJIact».

1) Раскрепощение женщин в СССР и полољкение женщин в панской Польще.

2) За.дачи экенщин в пре.дстоящих выборах.

На сцену ме.дленно с палючкой в руках по.днимается старушка лет 70-ти, бывІгая учительница тов. Гесионер. Она нам просто и внятно рассказала о том бесправном положении, в котором нахо.дились женщины в Западной Белоруссии. „Женщина, - говорит она, - терпела тройной гнет, национальный, религиозный и социальный. Она была скована и в быту. Поговорка о том, что «у бабы волос .длинен, а ум короток» была живуча в панской Полыпе, - она говорила на еврейском языке. - „Женщина не могла стать специалистом јғобой профессии. Единственно, чего мы могли добиться, это стать учительницей. И вот я отработала три.дцать лет в школе, а теперь я выброшена за борт. Мою старость никто не обеспечил. Вот такова былға наша зкизнь. Только Советская власть является действительно той властью, которая обеспечивает тру.дящимся спокойную, радостную светлую жизнь. Советская власть обеспечивает спокойную старость. Теперь, - говорит тов. Гесионер, - я знаю, что меня Советская власть не оставит. Поэтому мы все, как один, должны голосовать за нашего кан.ди.дата, что значит за Советскую власть". Всего на этом собрании высказалось 16 человек. Выступления были яркими, жкивыми, носили характер благо.дарности Красной Армии, тов. Сталину за то, что им была протянута рука братской помощи, и они были освобож.дены из-под ига шляхетской нечисти. Собрание мы закрыли, посынались апло.дисменты возгласы „Ура!" С лгозунгами: „Да з.дравствует освобожденная женщина Западной Белоруссии", „Долгие го.ды кузнецу счастья товарищу Сталину!" На всех языках белюр., полск., еврейском. Вечер закончился пением Интернационалга на всех языках

После этого Минским коллективом евр. Театра была .дана постановка «Тевье дер. милхикер». На этом же собрании актив женщин т.т. Каплан, Гесионер, Гримблат, Рудая, Фидерман и др. взяли на себя обязательства оборудовать избирательные участки, так чтобы их внепний вид привлек внимание напиих избирателей, что было сделгано. Художница Гримблат руководила ху.дољ. оформлением всех участков. 
21/X-39 г. Мы проверили все избирательные участки, готовность их к выборам. IІри чем на каждом участке доверенным участка был член партии. В частности, по 1-му участку был тов.Татарский (Минск), II уч. Епифанов (Москва), III уч. Топаз (Минск), IV уч. Захарова (Минск).

IІосле проверки участков мы вместе с активом по 2 человека проверяли работу агитаторов по домам. Мы взяли на вы,держку лучших и отстапших агитаторов. В частности, мы проверили работу т.т. Јившиц, Бассерман, Гутман, Рубинптейн и др. Мы проверили готовность списков избирателей. Трудность составления списков заключилась в том; что была болыпая текучесть со стороны беженцев. То они убывали, то прибывали.

21/X-39 г. в 10 часов вечера мы провели, совецание с агцтаторами и активом всего округа. Указали им конкретно на их задачи в день голосования $22 / \mathrm{X}-39$ г.

$22 / \mathrm{X}-39$ г. В 6 час. IІо моск. времени началось голосование. 3-й участок был оборудован замечательно. ІІотому что он размещался в танцевальной зале. Это былю одно из лучпиих помещений из двадцати избирательных округов. В третьем участке работала Московская кинохроника звукозаписи. Первыми приплли голосовать 50 человек, из которых была 70-летняя старуха Колубницкая Аделя. Она впервые голосовала в свого жизнь так радостно, с такой замечательной улыбкой, казалось, что ее счастью нет границ. А.деля всю своюо жизнь была у пана прачкой. А доля прачки, известная в панской Польпе. Впервые в свого зкизнь голосовала 18 летняя Cара Эпитейн. „Теперь, - сказала Сара, - все двери нам широко раскрылись. Канул гнет. Вместо слез мы теперь будем ра,доваться и смеяться со всей цветущей молодежьо Советского союза. Длинными вереницами пришли избиратели к избирательным урнам, чтобы первыми отдать свои голоса за $Ф$ анго Жегельницкую, за цочь трудового народа".

Старупка Гримблат Двейра проголосовала своей дрожацей старческой рукой, потом подонлла ко мне, набросилась на пею и от радоости зарыдала. $\oiint$ спросила у нее, чего она так плачет. Поступил ответ: „Нам хоропо. Мы счастливы. У нас большой праздник (пимхастейре)". Каменіпик тов. Горецкий, по нац. белорус, заходя в кабину для тайного голосования, подозвал меня к себе. Я быстро подошла и спрашиваю: „Неясно Вам что-либо папапа?" „Нет, - ответил он мне. И сказал: «Дочупка моя. Я неписьменны. ІІодпиши мне яго, 
гэтага, што на сцяне висиць. Сталина, нашага роднага и дарагога, любага нашага». Я не смела отказать ему в его просьбе. Приписала ему товариша Сталина на бюллетень. Старуха Гальперина Шивья, будучи абсолютно слепой, никому не доверила, чтобыкто-либо за нее голосовал, а сама дрожаџей рукой опустила свой бюллетень в урну. „За Советскую власть, - говорила она, - сама буду голосовать. Только сама". Все эти факты ярко свидетельствуют о том, что масса в больнинстве своем с исключительным подъемом, энтузиазмом голосовала за избранников народа, за тех людей, которые в Народном Собрании скажут свое слово. Мы за установление Советской власти. За воссоединение с БССР и вхождение в болыпую сов. семью СССР. За конфискацию помещичьих и монастырских-земель. За национализацию банков и крупной промыпленности".

Результаты проделанной работы:

Из голосуюших по 14-му избир. округу 99,87\%. за.канди,дата голосоваль $99,97 \%$.

Отрицат. факты:

В о,дном бюллетене фамилия -к-та была вырезана ножом. Н а 2-м бюллетени была записана канди,датура бывшей гор. голювы гор. Беэюстока.

24/X-39 г. Уполномоченный ШК по организации парт. работы города Белостока тов. Геравкер направил меня на прорыв в Мазовецк, там провалили две кандидатуры.

25/Х-39 г. Я приехала в Соколах, ибо Мазовецк как центр сгорел весь. Меня послали в распоряжение 27 избирательного округа. Округ послал в 8-й избирательный участок: Район тот по национальности преимушественно польский. Трудность наша заключалась в том, что агитационную работу на,до было проводить на польском языке.

25/X-39 г. Я провела общее єобрание в дер. Менжино и Перки- Франки. На этом собрании у нас была встреча с кан;дидатом в депутаты Наро,дного Собрания Шишко Францем А.дольфовичем. Настроение здесь было несколько иное. З.десь национальная рознь была исключительно болыная. Выяснилось, что местный ксендз им внушил о том, что все зло о том, что, мол, нет соли, спичек и керосина исходит от евреев. Они считают, что Советская власть т это еврейская власть. Пришлось раз'ьяснить этот вопрос. - Доказать на фактах, что неправильно они понимаюот. Мы показали на ярких примерах жизни нац. меныпинств в Сов: Союзе. Мы расска- 
зали о той дружбе народов, которая придает силу и мощь нашей стране и наоборот развал польского государства, потому что оно существовало главным образом на национальном угнетении народов. Әтот вопрос более подробно на польском языке разъяснил тов. IIІипюко.

Результаты голосования по 8-му участку следуюшие: из 100 голосующих за ІШишко Франца Адольф. голосовало по 8-му участку $54 \%$ „за", а по округу он прошел на $74,8 \%$. На 30 бюоллетенях по 8 участку из голосующих против было написано: „Нех жые Польша". На одном бюллетене было написано: „Не хочу власти Советской, а хочу власть Польскую Варшавскую". Надо понимать, что это былю написано осадниками, потому, что Перки-Франки населена осадниками. Однако абсолютное большинство трудящихся поляков голюсовало за кандидата Шишко.

Вот все те положительные и отрицательные моменты, с которыми мне в процессе работы с 9/X-39 г. по 24/X-39 г. приходилось сталкиваться.

(podpis)

Oryginał, maszynopis.

Źródło: NARB w Mińsku, zesp. 4, spr. 27, t. 69, k. 10-21.

a Duże litery i podkreślenia oryginału.

b Pierwsza część tego punktu zaznaczona odręcznie linią pionową na lewym marginesie.

c Słowa „przyszła do nas” wpisane odręcznie.

- Pierwsze trzy linijki tekstu tego akapitu zaznaczone linią pionową na lewym marginesie.

e Słowa „w języku żydowskim” skreślono i wpisano odręcznie „we wszystkich językach”. 


\section{Dokument 13}

1939 październik (po 28), Mińsk, - Sprawozdanie O. R. Jakielczyka z przygotowań i przebiegu wyborów do Zgromadzenia Ludowego Zachodniej Biatorusi $w$ Lidzie.

В ЩК КП(б)Б.

$\underline{\text { КОПИЯ }}^{a}$

От члена КП(б)Б ЕКЕЛЬЧИКА О.Р. место работы: Спиртотрест, инженер.

Докл адная.

ШК партии я был направлен в г. Јиду с 12/X по 28/X-39 г. на агитационную работу по выборам в Народное Собрание Западной Белоруссии.

Временное Управление г. Лида направило меня председателем участка № 6, имение Жижма Ш-Жирмуньской волости.

Население моего участка живет по хуторам и в преобладающем болыпинстве своем являются осадники, кулаки и неуспевшие, или не захотевшие сбежать помецики. В \% отношении бедняков меныше. По приезде на место мною с помоцью остальных членов избирательной комисси были проведены собрания (три раза) ${ }^{b}$ со всем населением моего участка, где проводилась самая широкая агитация за власть Советов, за немедленное разделение помецичьей земли, за выдвинутого кандидата и ряд других вопросов, связанных с Красной Армией, с землей, с советским бытом и т. д., и т. д. Вопросы, во время агитационной напей работы ставились со стороны населения моего участка, самые разнообразные. Особенно всю массу крестьян волнует вопрос о колхозах, т/е относятся отрицательно. Мною было безусловно разъяснено, что сейчас вопрос о колхозах в Западной Белоруссии стоять никак не может, даже.еслибы население захотело бы, ибо для этого у них нет никакой экономической базы. Все басни о колхозах, о том, что все колхозники едят с одного котла, все ходят в одной одежде и что болыпе как одну пару брюк колхозникам не разрепают иметь и тому подобная чепуха, разъяснена нами была в должной мере и определенной ясностью.

Бедняцкое население моего участка приняло самое активное участие в выборах, помогало нам в организации собраний, распростра- 
нением лозунгов и другой помоши. Но зато я почуствовал самое бешенное сопротивление со стороны остального населения - осадников. кулаков, помещиков и бывших польских офищеров. Своюо агитационную работу они противоставили вполне открыто нашей болышевистской, причем надо сказать, что некоторая часть бедняков, запуганная ими, что: „мол, скоро придут опять паны и тогда расправятся с вами" оказала в некоторой мере свое цолжное влияние на них, спедствием чего и явилось их отрицательное голосование против выставленного кандидата. Я на каждом шагу чуствовал их антисемитское настроение к себе. Как потом оказалось, мне один бедняк рассказал, что они вели агитацию против выставленного кандидата только потому, что „жид” возглавляет участок. Вся подготовка к выборам проходила в имении бывшего помешика удравшего после прихода Красной Армии. Благодаря оставленной пианино нами каждый вечер организовывались собрания молодежи окружаюших хуторов, где разучивали с ними наши советские песни и танцы. Эти вечера, где, вполне понятно, без агитац. работы не проходило, внесло очень много ясного в сознание молодежи Запацной Белоруссии о нашей советской действительности. Особенно остро у них было распространена клевета, что, мол, когца рождается ребенок, то его наше Правительство от матери отрывает и только іосле того, как ему становится 10 лет его возврапают матери. IІричем в течение этих 10 лет мать не имеет право видеть своего ребенка. Вот такая чепуха и еше ей подобная нами разъяснена была молодежи, как самая злостная клевета на советский быт. И они әто прекрасно поняли.

Как и следовало было ожидать, в связи с тем, как я уже указал выше, на моем участке преобладало большинство осадников, то в результате подсчета голосов, против кандидата оказалюсь $70 \%$, a за - 30\%. Кроме того, при раскрытии бюллетеней были найдены такие, в которых было обнаружено следующее:

1. Фамилия, имя и отчество кандидата было вычеркнуто, а под ней пригисана фамилия - Рыдз-Смыгла.

2. Фамилия кандидата вычеркнута и написано: „Еше IIольша не сгинела".

3. Фамилия кандидата вычеркнута и написано: „долой советскую власть".

4. На 5-6 бюллетенях были специально вырезаны фамилии кандидатов и так брошены в урну.

5. ${ }^{c}$ Много бюлюетеней были обнаружены, где фамилия кандидата 
была вычеркнута различными цветными карандашшами, что говорит за то, что эти враги преднамеренно уже не стеснялись и открыто показали свое лицо.

В общем. по моему округу. кандидатура провалена не -была. Голосовало за - $65 \%$. Кроме выборов, мною была проведена широкая агитация против рубки леса, против разграбления помецичьего имушества, за сохранение оставшегося имущества и т. д.

Из положительных моментов, хочу отметить исключительно сердечный прием меня и остальных членов комиссии среди бе,дняцкого населения участка. Нам приносили каждый день мёд, масло, хлеб, мясо. Денег они у нас ни в коем случае брать не хотели. Со мной был еще один красноармеец, то его буквально на руках носили. $\mathrm{C}$ исключительной охотой разучиваются всем населением напи веселые советские песни. Не могу выразить того воодушевления и энтузиазма, который царит в связи с прихо.цом Красной Армии, особенно среди еврейского населения. Мне приходилось говорить с безработными инженерами, врачами и остальной интеллигенцией, которые исключительно радушно встретили освобождение Западной Белюруссии от панского ига, ибо как они сами говорят: „только Советская власть и обеспечит нас работой, конец пришел безработице и национальному угнетению. Теперь мы заљкиваем счастливой радостной жизнью".

Вот, примерно, в таких кратких словах и заканчивался мой разговор с собеседником.

$$
\begin{aligned}
& \text { Инженер Спиртотреста } \\
& \text { (по,дпись) ЕКЕЛЬ ЧИК }
\end{aligned}
$$

Kopia, maszynopis.

Źródło: NARB w Mińsku, zesp. 4, spr. 27, t. 69, k. 29-32.

a Duże litery i podkreślenie przerywaną linią oryginału.

b Podkreślenia w tekście dokonano w trakcie czytania.

c Punkt zaznaczono na lewym marginesie pionową linią. 


\section{Dokument 14}

1939, październik ${ }^{\mathrm{a}}$, Biatystok, - Raport z przebiegu wyborów do Zgromadzenia Ludowego Zachodniej Biatorusi w powiecie biatostockim.

\section{Зав. Оргинструкторским Отделом ІК КІІбБ}

Тов. Эидимову

У полномоченному Ц. К. КПбБ по Белостокской области тов. Игаеву.

\section{Докладная записка}

„О итогах проведения выборов депутатов в Народное Собрание Западнои Белоруссии по Белостокскому уез,ду."

Вся агитационно-массовая политическая работа в период подготовки и проведения выборов депутатов в Народное Собрание Западнои Белоруссии проходила под лозунгами: присоединения Западнои Белоруссии к БССР и СССР, установления на терри'гории Западнои Белоруссии Советской власти, национализации помещичьеи земли, национализации крупнои промышленности и банков.

Рабочии класс, крестьянство и другие слои трудящегося населения Белостокского уезда в абсолютном своем большинстве приветствовали решление советского правительства о мерах запиты народа Западной Белоруссии.

Обращение Временного Управления города Белостока население повсеместно встречало с больщои радостыо с исключительным подъ емом.

Пункт обращения где говорится:

„Население Западнои Белоруссии полно решимости, на основе ленинско-сталинской национальной нолитики, вместе со всем советским народом, вместе с трудяпцимися Советской Белоруссии строить новую, светлую, радостную жизнь, под солнцем Сталинской Конституции", вызывает не только чувство радости и любви к РККА, Советскому правительству и любимому вождю тов. Сталину, но вместе с әтим вызывает глубокую ненависть к капиталистическому строю, ко всем врагам народа, которые мешают проводить дальнеипую работу по упорядочени дел после военных деиствии на територии Западнои Белоруссии. 
Согласно положеня о выборах депутатов в Народное Собрание по Белостокскому уезду было создано 30 округов в состав которых было подобрано и уверждено 210 человек членов из них 30 председателеи окружных комиссии, 30 заместителей председателей и 30 человек секретарей. Вместо с этим было создано 190 участковых комиссии с количеством 1330 человек членов из них 190 председателей участковых избирательных комиссии, 190 заместителей и 190 секретарей. $^{\mathrm{c}}$

Всего в состав окружных и участковых комиссии было подобрано 1540 членов, из них по национальности: Белоруссов 692, русских 230. евреев 355 , поляков 209, прочих 54 . По социальному појожению: рабочих 498, крестьян 802 , служащих 175 и прочих 65 человек. $^{c}$

Во время подготовки к проведению выборов работало по уезду более 2500 тысяч агитаторов из них 220 из частей PККА и более 2300 из местного населения. В число этих агитаторов входит 190 человек доверенных участковых избирательных комиссии. В числе агитаторов насчитывается более 600 человек женщин. Помимо этого 280 женщин принимали активное участие в украшении помешении участковых комиссии поселков, городов и деревень.

В период подготовки к выборам было проведено посвяшенных к выборам депутатов в Народное Собрание в городах, селах и деревнях Белостокского уезда 195 митингов с охватом более 75000 жителей, проведено бесед и собрании по вопросу разяснения положения о выборах депутатов в Народное Собрание 58 с охватом более 85 тысяч человек. $^{\text {d }}$

Выборы депутатов в Народное Собрание Западной Белоруссии прошли с болыним подъемом. Вот положительные примеры:

На 1 участке 34 избирательного округа (Заблудов) из местного населения определился актив в количестве 16 человек который был использован для организации работы на участке. Всех избирателей по два раза обошли по квартирам, провели два митинга. На митинге, который состоялся 13 октября присутствовало 1500 человек. Митинг прошел с болышим подъемом, он превротился в демонстрацию преданности великой партии Ленина-Сталина. На другом митинге, который состоялся 19 октября с масс неслись лозунги "Спасибо Великому Сталину за освобождение Западнои Белюруссии и Западнои Украины”. На митинге дружно кричали „У ра Великому Сталину". 
Radzieckie dokumenty o przygotowaniach do wyborów do Zgromadzenia Ludowego... 313

На двух предвыборных собраниях этого же участка выступило 16 человек из местного населения. Выступавшие говорили о безграничной любви к социалистическои стране, Красной Армии и Великому вождю народов Сталину.

В день выборов депутатов в Народное Собрание Западнои Белоруссии избиратели начали собираться к участку еше до 6 часов утра. Голосование началось и проходило организовано. Состоялясь демонстрация избирателей в количестве 800 человек, которая пропाла по улицам с лозунгами и пением интернационала. Подсчет голос потвердило хорошое настроение избирателей. Было подано за кандидата 849 голосов, против 51 , неявилось - 3 . По другим участкам 34 избирательного округа также отмечено организованность и активность населения. На избирательный участок № 2 (город Заблудов) явилось для голосования $100 \%$ избирателеи из которых подали голоса за кандидата $97 \%$. На избирательныи участок № 3 зівилось для голосования $99,6 \%$ избирателей из которых голосовало за $93 \%$. Эти данные и итоги выборов по всему Белостокскому уезду показывают, что абсолютное болышинство населения ( $77 \%$ голосовавпих) голосовало за выдвинутых депутатов, за присоединение Западнои Белоруссии к БССР, за установление Советской власти, за раздел помецичьеи земли, за национализацию крупной промыпленности и банков.

До выборов и во время голосования враждебные силы проявляли активность, они пытались помешать успешному проведению выборов депутатов в Народное Собрание Западнои Белоруссии. На собраниях пю деревням Завыковскои гиины задавались вопросы такого содержания:

„Говорят, что в советском союзе отбер.яют от матери ребенка и она его больше не видит".

„Мужчины в советском союзе имеют пю две, три жены и живут с ними по очереди".

„Колхозники не имеют своих домов, а живут все в одном доме и спят все на одной коике и под одним одеялом".

„Колгхоники питаются все с одного котла и одной пишей, всегда ходя за супом со своим котелком".

„'оворят, что Красные начинают отступать, значит придут паны, а поэтому землю делить нельзя".

„Говорят, что в Советском союзе женцины ходят не в платьях и не в юбках, а в мешках". 
„Говорят, что если установится Советская власть, то начнут сразу гнать все в колхозы, кто хочет и кто не хочет".

„Говорят, что в советском союзе закрывают церкви и ключи находятся у евреев и если кто захочет итти в церковь, то надо итти к евреям и просить ключ от церкви". $е$

Имели место контреволюционного характера деиствия со стороны врагов. Так на 6 избирательном участке 34-го округа в ночь с 21 на 22 октября группой, в которую входили Конынчук Станислав, Конынчук Бронислав, Дроздовский Бронислав, проживаюоцие в деревни Сисках, был сорван на участке флаг и несколько лозунгов. Избирательная комиссия этого участка к работе приступила с болыпим опозданием. Подобныя враждебныя деиствия имели место и по 4-му избирательному участку 49-го избирательного округа (Ясиновка). Так в деревне Коменка, Калиновскои гмины были сорваны все лозунги, на которых нахо,цились портреты Ленина и Сталина, два раза срывались флаги, через окно в избирательную комиссию был бропен камень. Были случаи, что во время голосования на бюллетенях фамилии депутатов зачеркивались и вместо них писали контрореволюционные лозунги „Пусть живет Полыпа. Долой Советы". Так было на Завыкской и Гониондской гминах. ${ }^{c}$ В отдельных случаях вместо бюллетеней в конверты вкладывали портреты Мостицкого и других врагов. Отдельные бюллетени обнаружено разорваными. В некоторых местах (Гониондз, Ясиновка и другие) были обнаружены антисоветские листовки напечатанные на польском языке. Следует указать и на такой характерный факт, как влеяние церкви на избирателеи. С утра многие избиратели 22 октября пाли в костел и только потом приходили на избирательный участок длэя голосования (Завыковскии избирательный участок).

Но не смотря на все эти и подобные происки и деиствия враждебных элементов, развернутая массово-политическая работа в Уез.це обеспечила новую победу - все кандиддаты по Белостокскому уезду были избраны. В голосовании приняло участие $93 \%$ избирателей, из них за выставленных кандидатов голосовало $77 \%$.

IIо от,дельным округам материал прелогается.

Председатель Временного Управления Белостокского уез.да (Доровко) Уполномоченный ШК КПбБ по Белостокскому Уезду 
W końcu raportu odręczny nieczytelny tekst. Prawdopodobnie następującej treści: „W Knyszynie wystawiono bez wiedzy kandydata i podano na. niego 54 głosy".

Kopia, maszynopis.

Źródło: PAOSOG w Grodnie, zesp. 6198, spr. 1, t. 5, k. 12-14 (obustronne).

a Brak daty, sprawozdania $z$ innych powiatów składano w kilka dni po wyborach, np. pow. szczuczyńskiego i miasta Białystok 26 X 1939 r.

b W tym miejscu podkreślenie oryginału.

c Podkreślenie w oryginale dokonane podczas czytania.

d Akapit na marginesie zaznaczony dwiema liniami pionowo.

e Cytowane wypowiedzi na marginesie zaznaczono linią pionową.

\section{Dokument 15}

19392 listopad, (Biatystok), - Raport petnomocnika KC LKZMB na woj. biatostockie o udziale mtodzieży w wyborach do Zgromadzenia Ludowego Zachodniej Biatorusi.

\section{СЕКРЕТАРЮ ЦК ЛКСМБ тов. ГОЛОВКИНУ \\ От уполномоченного ЦК ЛКСМБ по белостокской области т. Печуренко}

\section{Докладная записка ${ }^{2}$}

За период подготовки выборов в Народное Собрание уполномоченному ЦК ЛКСМБ по уездах и городах Белостокской области и осушествлении указаний ЦК КІІ(б)Б проведено следующие мероприятия:

а) По городам: Белосток, Гродно, Волковыск, Соколка, Ломжа, Аугустово, проведено 84 собрания молодежи, на которых были поста,влены доклады на темы: Ленинско-сталинская национальная политика и жизнь моліодежи в СССР а также организовали встречу молодежи с выдвинутыми кан,ди,датами в депутаты Наро,дного Собрания.

б) По избирательным округам г. г. Гродно, Белосток, Волковыск проводились митинги молодежи, на которых молодежь рассказывала 
о прокллтом пронлом и своих за,дачах в восстановлении Советской власти в Западной Белоруссии!

в) По болынинству избирательных участков, особенно в городах, проходились собрания молюдежи, на которых были определены задачи моло,дежи в связи с подготовкой и проведением выборов в Народное Собрание.

г) В городе Белосток в честь выборов в Наро,дное Собрание был организован 15 октября вело-побег, в котором участвовало 125 человек молодежи.

Колона велосипедистов была оформлена люзунгами, плакатами гризывағоцими избирателей организованно проголюсовать за избранников народа.

Велосипедисты провели 2 митинга, на которых проводили агитационно-массовую работу.

д) В некоторых избирательных округах - Белосток, Гродно, Волковыск, Ломља устраивались вечера ху,дожественной самодеятельности, посвященные выборам в Народное Собрание, на которых молодежь выступала с пением советских песен, декламацией стихотворений советских поэтов итд.

В Гродно был организован любительский, молодежкный драматический кружок, сизами которого дано 7 постановок в волостных центрах Гродненского уезда.

11." Bсе комсомольцы, мобилизованные на работу в Белостокскую область IIК ЛКЗМБ принималюи активное участие в работе по подготовке и проведению выборов в Народное Собрание.

IIо Белостокскому, Гро,іненскому, Јомэкинскому, Волковыскому, Августовскому, Соколковскому, Граевскому уездов председателями окруљкных избтрательных комиссий работали 24 комсомольца, секретарлми окружных комиссий 13 комсомольца, членами окруљкных комиссий 129 комсомольцев. Доверенными на участках 63 комсомольцев. ІІредседателями участковых избирательных комиссий 155 комсомольцев. Секретарями участковых избирательных комиссий 313 комсомольцев и молодежи.

Необходимо отметить, больную активность среди молодежи Западной Велоруссии в период подготовки выборов в Народное Собрание. Только по 3-м уездам: Белосток, Гроцно, Волковыск работали в перио,ц избирательной кампании агитаторами 637 человек, председателями окружных избирательных комиссий 18 человек, председателями участковых избирательных комиссий 289 человек, членами 
избирательных комиссий 636 челювек.

Таким образом по трем уездам участвовало молодежи в выборной кампании до 1400 человек. Больпинство из них оправ.дало себя на этой огромной работе. В Белостокском уезде тов. Хроменжиџкая Брайна Абрамовна, 1917 г. рождения, работала председателем Тростлнского избирательного округа, проводила огромную политическую работу среди избирателей своего округа и добилась при огромной помоци, в округе $93 \%$ участвуюших в голосовании.

В Гро,цненском уезде активисты из местной молодежи Пугачевская, Коляда, Сецько, Пугач и др. были прекрасными агитаторами на участках.

В местечке Голондз отряд рабочей гвардии состоит из молодежи во главе с 20-летним Заренгольским М. JI. В перио.д выборов отря.д принлл все необходимые меры по охране избирательных участков и избирательных документов.

Большую работу проделала молодежь по оформлению избирательных участков, как в городе так и в деревне.

В результате большой работы проведенной партийной организацией, при активной помощи комсомольской организации, выборы депутатов в Народное Собрание Западной Белоруссии прошли на высоком идейном, политическом у ровне.

По Белостокской области с 859.010 избирателей приняло участие в голосовании 803.871 человек или 93,9\%. За кандидатов голосовало 678.930 человек или $85 \%$. Против кандидатов голосовало 119.379 ч. или $15 \%$. Признано недействительными 5547 бюллетеней. IIо городу Белостоку с 83.035 избирателей приняло участие в голосовании 81.873 челювек или 96,6\%. Против кандидатов голюсовалю 3.002 или 3,4\%. П ризнано недействительными 167 бюллетеней. По городе Гродно с уездом с 138.018 избирателей приняло участие в голосовании 134.904 человека или 92\%. За кандидатов голосовалю 123.650 или 92\%. Против кандидатов голосовало 10.766 человек или 8\%. Признано недействительными 478 бюллетеней.

Командированные в Белостокскую область 335 комсомольцев распределены по уездам следуғошим образом:

В Белостокский уезд и город 75 человек, Бельский -..- 15 чел,, Гродно - 51 человек, Августово -- 23 человека, Ломжа - 28 человек, Соколка - 20 человек, Волковыск - 29 человек, Кольно - 12 чел., Граево - 37 чел., Высоко-Мазовецкий - 47 человек (списки уточняются). 
ІІроведены комсомольские собрания по Волковыскому, Граевскому, Белостокскому, Гродненскому и др. уездам, где были обсуждены вопросы о задачах работы комсомольцев Западной Белоруссии. В Гродненском, Белостокском, Граевском, Августовском, Ломжинском, Волковыском, Сокольском созданы первичные комсомольские организации. Всего по Белостокской области на $1 / \mathrm{X}-39$ г. соз.дано 28 первичных комсомольских организаций. Плохо идет создание организаций в г. Белостоке, где еще до сего времени не созданы первичные комсомольские организации. Такое же полољкение в Кольненском уезде.

Комсомольские организации главным образом создаются при гминах и временных управлениях. Так, в Августовском уезде созданы первичные организации при временном управлении уезда, голынской гмине, дет.доме и 4 партийно-комсомольские группы. В Бельском уезде созданы первичные комсомольские организации при Брянской, Наревской, Тихоповецкой, Ботьковской и Клешеливской гминах. В г. Гродно первичные комсомольские организации созданы при временном У равлении, уполномоченном ЦК ЛКСМБ, оперативном отделе НКВД. Уполномоченным ЩК ЛКСМБ для ознакомления и изучения молодежки проводится учет бывших комсомольцев Западной Белоруссии. Так, по Белостокскому уезду зарегистрировано 25 .человек, по г. Белостоку 10 человек, по Августову 15 человек. Прово.дится учет бывшего руководяшего состава комсомола Западной Белоруссии (секретари горкомов и окружкомов). Вся әта работа проводится для того, чтобы ближе ознакомиться и изучить бывших комсомольцев и их руководителей.

Проводим работу по укомплектованию штатов областного и уездных комитетов комсомола. На 1/XI-39 г. в областном комитете подобраны 4 единицы на ответственную работу в областной комитет, на которых характеристики будут высланы дополнительно. Недостает к полному укомплектованию штата зав. отделюв 3 человека. В 7 уез.цах подобраны штаты уездных комитетов комсомола из числа лучних комсомольцев направленных для работы в Западную Белоруссию. Так, в Белостокском уезде на работу зав. отд. пропаганды и агитации выдвинут Гайшунов, по национальности белорусс, 1908 г. рождения, образование 9 классов, член ВЛКСМ с 1930 г., член КП(б)Б с 1937 года. Долгое время работал на руководяшей комсомольской работе. На работу зав. учетом выдвинут тов. Качан - 1921 г. рождения, член ВЛКСМ с 1931 г., образование вы- 
сшие. На работу зав. отделом пионеров выдвинут Грипкин - 1921 г. рождения, образование 8 классов, окончил курс пропагандистов при IIK JIKCM, работал зав. от.д. пионеров Лиозянского РК ЛКСМБ; комсомольскую работу знает хорошо.

В 5-ти уездах Белостокской области на 1/XI - штаты еще неукомплектованы, к 5/XI - эта работа бу.дет закончена, списки и характеристики на пштат областного комитета и уездных комитетов будут досланы в IIK ЈKCM .

Далее следует отметить, что деятельность некоторых ранее супествуюших к/революционных организаций молодељки „до настоящего времени не прекращена. Так, 18 октября в 11 часов вечера по уличе Липова в г. Белостоке было созвано подпольное собрание бывпих работников физкультуры, куда вошли прежние руководители физкультуры и некоторые руководители всевозмољкных партий „Бунца", „ПІІ " и др. Организатором этого собрания оказалгя некто Литке, который был раныше руководителем физкультуры в Белостокском воеводстве. Литке личность довольно подозрительная. В 1933 году он переехал из Германии для работы на польской территории. В настояпее время Литке задержан органами НКВД .для выяснения .

На ряду с другими к/революоииоными организациями особый интерес представляет молодежная организация под названием „Коммуна" находившаяся в г. Гродно. Состоит организация из 17 человек, руководитель этой организации Зенобен Амбаль. Состав главным образом из купцов и торговцев еврейского населения. Из 17 чејовек 10 парней и 7 девушек. Ж $и$ иву все в одной комнате, носят одинаковую одежду, работают на разных работах, заработанные деньги каждым членом коммуны сдағотся своему руководителю, который распределяет деньги для существования всех. Себя они называюот „революоиионерами". Имеется у них библиотека, в которой главным образом находится троцкистская литература. Их политическое направление выясняется.

В большинстве местечек, где преобладает еврейское население существовали сионистские организации. Членами организации были в болынинстве купцы, лавочники, ремесленники и фабриканты. Членом организации считается каж,дый, который покупил членский билет „шекель", дающций право голоса при выборах в сионистский конгресс. Сионисты открыли широкую сеть пाкол на древне-еврейском языке (язык являюшийся обиходным в Палестине). Эти пाколы посе- 
цало около 800 детей и молодежи. Далее организации „сионистов-ревизионистов" или новая сионистская организация Жаботинского. К этой организации проникала главным образом мецанская молодежь. В последние время сионисты-ревизионисты организовали нелегальную эмиграцию своих членов в ІІалестину.

Одновременно со стороны некоторых комсомольцев командированных для работы в Белостокскую область допущена прямая потеря большевитской бдительности. Например: Душкина Рива, комсомолка г. Гомеля, познакомившись с одним из местных жителей в г. Гродно и доверила ношение своего комсомольского билета ему. ${ }^{c}$ Комсомолка Хорова работавшая в Августовском уезде получая от продавцов товары не сплачивала их стоймость, тем самым дискридитировала звание советского гражданина.

Комсомолка Розина работавшая во временном управлении Белостокской области в беседе с руководящими товарицами области, где присутствовали политзаключенные, задала такой вопрос: „Как мы будем засылать товары в Западную Белоруссию, когда их нехватает у нас в Советском Союзе?"

В порядке по,дготовки к XXII-й годовпцине Октябрской социалистической революции согласно составленного плана уполномоченного ІІК ЛКСМБ по области, с 1 по 4 ноября проводятся собрания молодежи по предприятиям, гминам, школам. В ря,де мест по.цготавливаем художественную самодеятельность из местной молодежи. 7-8 ноября организуем детские утренники по школам. В день демонстрации в г. Белостоке, Гродно, Волковыске организовывағотся велгоколоны из молюдежи и ряд др. мероприятий.

\section{УПОЛНОМОЧЕННЫЙ ІІК ЛКСМБ ПО БЕЛОСТОКСКОЙ ОБЛАСТИ (podpis) (Печуренко)}

2/XI-39 г.

Oryginal, maszynopis.

Źródło: PAOSOG w Grodnie, zesp. 6218, spr. 1, t. 28, r. 101-108.

a Podkreślenia i wielkie litery oryginału.

b Tak w oryginale.

c Ten akapit zaznaczony na lewym marginesie pionowym wężykiem zielonym atramentem. 


\section{Dokument 16}

1939 listopad 2, Mińsk, - Sprawozdanie Kaszczejewa - aktywisty z Mińska $z$ udziatu w kampanii wyborczej do Zgromadzenia Ludowego Zachodniej Biatorusi w powiecie wotkowyskim.

$\underline{\text { Не подлежит оглапению }}^{2}$

ПК КП(б)Б

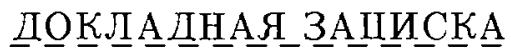

Будучи командирован Вами для агитационной работы в Волковыский уезд Зап. Белоруссии, где участвовал в проведении следующей работы: был председателем участковой избирательной комиссии 5-го избирательного участка, в который входило исключительно польское население деревень - Ясеновица и первая и вторая Бачицы. Мною в этих деревнях проведено предварительно до выборов в депутаты Народного Собрания Зап. Бел. 7 общих собраний с постановкой вопроса о причине развала польского госу.дарства и освобождения Красной Армией Зап. Бел. и Украины от польско-капиталистического гнета, об успехах социалистического строительства народов СССР. В этих вопросах крестьяне интересовались всеми вопросами социалистического строительства народов СССР и приветствовали советское правительство, Партию и его Красную Армию, принесшую им освобож,дение от польско-помецичьей кабалы.

В своих выступлениях крестьяне, как-то Юречко Иван и др., говорили: „Нас польские власти давили со всех сторон непосильными налогами, штрафами, если еще пару годов просуществовалю бы польское буржуазное государство, то нам всем пришлось бы, наверное, умереть от голода". Многие крестьяне первой и второй Бачицы говорили на собрании: „Только Красная Армия принесла нам освобождение от панской кабалы, нас мучили налогами, штрафами, не давали свобо.дно говорить. Спасибо тов. Сталину и Красной Армии за освобождение нас от гнета".

Крестьяне с радостью и удивлением встретили в вопросе, когда услыпали, что в Советской стране дети во всех учебных заведениях, высших и низших, учатся бесплатно, что медицинская помоць оказывается бесплатно. Помещение избирательного участка было оборудовано в сельской школе Красными флагами и достаточным количе- 
ством јозунгов с портретами тов. Сталина. В оборудовании участка приняли участие члены избирательной комиссии. На выборы для голосования явились в 7 ч. утра и закончено в 9 ч. вечера, не принимали участие только два человека по неуважительным причинам. На собраниях в своем наказе избираемому депутату требовали о голосовании за восстановление Советской Власти в Зап.Белоруссии, о присоединении к Советскому Союзу, о конфискации помецичьей земли и передаче ее крестьянству и о конфискации банков, фабрик и заво.дов капиталистов.

Из зажиточной части польского населения напюлись и такие лица, которые не только голосовали против вы,двинутого кан.ди,дата в депутаты народного собрания Юречко И. В., жителя дер.За.дворье, крестьянина-бедняка, но и наоборот на избирательных бюллетенях при голосовании в кабинах писали на польском языке „нех жые польска зброя, нех жые полыша; долюй коммуну" и т.д. В результате голосования против канди,дата в депутаты народного собрания $29,1 \%$ общего числа голосуюших.

Со стороны Волковыского В.ременного Управления никакой подготовительной :работы к выборам в данном участке проведено не было и руководство работой по выборам также не было, так как по приезде на место $13 / \mathrm{X}-39$ г. приплоось наяинать работу с составления списка избирателей. Было видно, что многие коман,дированные тов. для агитационной работы по линии ШК работали без руково.Дства и контроля со стороны временного управления.

\section{Член ІК(б)Б Кашеев}

Госарбитраж при Минской области

2/XI-39 г.

Oryginal, maszynopis.

Źródło: NARB w Mińsku, zesp. 4, spr. 27, t. 69, k. 225.

a Podkreślenia przerywane i duże litery oryginału. Pozostałe podkreśleniạ dokonane podczas czytania dokumentu. 


\section{Dokument 17}

1939 listopad 4, Baranowicze - Informacja petnomocnika $K C K P(b) B$ na powiat baranowicki z dziatalności organizacyjnej i masowo-politycznej $w$ powiecie w czasie wyborów do Zgromadzenia.Ludowego Zachodniej Biatorusi.

Заведующему Орг. инструкторского отделг IIK КП(б)Б

Тов. ӘЙдИнОВУ

г. Минск ${ }^{\mathrm{a}}$

\section{ПОЛИТИНФОРМАПИЯ}

О проведении организационно-массовой политической работы

в перио,ц по,дготовки и выборов кан,дидатов

в депутаты Народного Национального Собрания

Западной Белоруссии по г. Барановичи и уез.цом

Для проведения агитационно-массовой политической работы среди трудяпцися Барановичского уезда было послано в волостные крестьянские и сельские комитеты 250 человек агитаторов, кан-

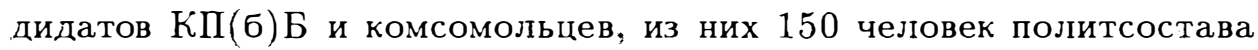
Рачоче-Крестьянской Красной Армии.

За этот период во всех деревнях и селах в течение целого месяца проводилась организационная политическая раз'ьяснительная работа среди населения. Среди населения изучались: положение о выборах в Депутаты Национального Собрания, Сталинская Конституция, порядок выборов и голосования, а также ставились доклады о международном положении. Население везде и всюду встречало напих агитаторов с болыпой радостью и воодупевлением.

За период с 1-го по 22-е Октября с.г. проведено 420 собраний по разьяснению избирательного закона, из них по городу -45 , по селам и деревням - 375. На этих собраниях присутствовало 45.000 человек населения.

Прове,дено митингов в перио.ц встречи цепутатов со своими избирателями - 375 , охвачено населения 38.000 человек. Предвыборных митингов проведено по городу 7 , по деревням - 32 , охвачено населения 18.000 человек.

Проведено 4 совецания окружных и участковых избирательных 
комиссий. Помимо этого в каж.дой волости прово.дились инструктивные совещания с участковыми и избирательными комиссиями.

За перио.д по.дготовки и хода выборов распространено 2500 экз.газет, 5.000 книг и брошюр, лозунгов и плакатов, посв.ященных выборам, -8.000 экз. Портретов наших вождей и руководителей партии и правительства 3.000 экз. 45.000 экз. тираж местной газеты «Голос рабочего».

Помимо всего активное участие принимали бригады артистов, прибывпиих из г.г. Минска, Ленинграда и других городов Советского Союза. Всего .дано концертов - 26, из них по городу - 15 , в селе - 11 , охвачено населения 31.000. Было дано 39 киносеансов и 18 кинопередвижек в .деревнях, всего охвачено населения 15.500 человек.

О.дновременно соз.дан кружок ху.дожественной самодеятельности, музыкальный кружок, которые также принимали активное участие в обслуживании избирателей. Во время концертов и киносеансов проводились короткие беседы на тему значения выборов депутатов в Национальное Наро.дное Собрание. Население наших артистов встречало с болыной люобовью. Так, например, в Ново-Мыпгской воліости по окончании концерта ленинградских артистов выступили крестьяне, вынесли болыную благодарность нашим артистам и просили передать болыное спасибо Великому Сталину, тов. Молотову, Вороілилову за то, что они помогли избавиться от польского, помецичьего, капиталистического гнета.

Такие же отзывы по Ляховицкой волости, Даревской и другим населенным пунктам, где выступали наши артисты.

Болыную работу проделал также напі комсомол. Все члены комсомола являлись агитаторами по раз'ьяснению избирательного закона, рассказывали о технике выборов и голосования, помогли крестьянской молодежи во время выборов организовать стенную газету в Даревской волости, Ястребинской, Ляховицкой и т.д.

Проведено болыше 10 митингов молодежи, 500 человек беспартийной молюдежи было привлечено к агитационной массовой работе в г. Барановичи. Во всех селах, там, где побывали напи комсомольцы, накануне выборов и в день самого голосования 22 октября было большое торжество и веселье. В каждом селе играла музыка, комсомол сумел с крестьянской молодежью разучить советские песни о Сталине, о Ворошилове и ря.д других. Организованы были танцы, все улицы в помецении были украшены лозунгами, плакатами и красными флагами. 
Radzieckie dokumenty o przygotowaniach do wyborów do Zgromadzenia Ludowego... 325

Были случаи, когда население 22-го октября с утра не шли на голосование (например, в деревнях Литва Даревской волости, Новая Мыпь Ново-Мышской волости). Но, когда комсомольцы разослали крестьянскую молодежь по квартирам и раз'яяснили значение выборов в этих селах, на участках к 2-м часам полностью было закончено голосование.

Особенно хорошо работали комсомольцы: Сущеня, Бернин, Денисова и ряд других. Одновременно комсомольцы, в момент подготовки к выборам провели большую работу по организации красных обозов с продуктами, хлебом для города Барановичи.

В результате отправки продуктов и хлеба в город резко снижены цены на рынке на продукты. Так, например, если в первые дни нахождения наших войск на территории города и уезда на рынке не было совериенно продуктов, то ко дню выборов было продуктов достаточное количество и цены на продукты пали болын чем на полювину.

В момент подготовки к выборам наши агитаторы сумели привлечь в качестве агитаторов местный сельский и городской актив, трудовую интеллигенцию. Всего из местного населения принимало участие в агитационной работе 2650 человек. Особенно хоропю работали агитаторы Кривошинской волости Иванов Константин Александрович, Мишкевич Адам Васильевич, Зубик Григорий Алексеевич, Сейгель Андрей Андреевич и ряд других. В Городищенской волости - Старовойтов Петр Григорьевич, Кунцевич и т.д.

Со всеми агитаторами проводились несколько раз инструктивные совещания, весь этот актив взят на учет первичными партийными организациями и в настоящее время привлечен к работе по раз'яснению решения Народного Национального Собрания и подготовке ко дню Октябрьской Социалистической Революции.

Все изложенные проводимые мероприятия Временным Управлением и партийными организациями обеспечили день выборов 22 -го октября с болыпим политическим под'ьемом и блестяшими результатами. По всем избирательным округам из общего количества зарегистрированных избирателей 103.820 человек присутствовалю на выборах 102.676. Голосовало за кандидатов в депутаты Народного Национального Собрания - 99.381 чел., что составляет 98,9\%. При чем по 6 избирательным округам принимало участие $100 \%$ всех избирателей, а также $100 \%$ голосовало за выдвинутых кандидатов.

Все выдвинутые кандидаты Временным Управлением, Общим 
Собранием рабочих, интеллигенции, Волостными Крестьянскими Комитетами были избраны и, будучи в Народном Национальном Собрании, целиком и полностью выполнили волю трудягцихся Западной Белоруссии.

Во время голосования можно привести тысячу важных примеров. Старики, старухи приходили на избирательные участки в 3-4 часа утра, до начала голосования, ожидали, чтобы первыми проголосовать за великое счастье и свободу и за своих кандидатов.

Так, например, по Городскому 3-му избирательному округу прибыла на голосование старушка 80 лет Наскович Анна Григорьевна, беднячка, которая на участке заявила: „Я в своей жизни иду первый раз на голосование. Нет лучшего счастья и радости, как голосовать за Советскую власть. Я свой голос отдаю за лучших сынов народа". По 2-му участку 2-го избирательного округа прибыл на избирательный участок раньше всех старик 75-летний Заблоцкий, который заявил: „Я хочу голосовать в первую очередь за Великого Сталина и за свой народ". По 20-му сельскому избирательному округу Ляховицкой волости, на голосование пришла старушка 100 лет Калоша Анна и заявила председателю комиссии: „Я прожила 100 лет, не знала, что такое свобода, что человек бе.дный, безграмотный может свободно выбирать, кого он хочет. Поэтому я пришла первая и буду голосовать за Советскую власть". По 2-му участку того же избирательного округа прибыл на участок Левин Вульф, старик, имеет 75 лет, бедняк. Заявил председателю комиссии: „Я буду голосовать за Великого Сталина, за Советскую Власть и за своего кандидата". В каждом округе были такие заявления, а у нас их было 40 избирательных округов и 375 избирательных участков.

Какие были обнаружены отрицательные моменты. Нужно отметить, в населенных пунктах, где большая прослойка польских оса,дников, жандармов и полицейских, часть польского населения на голосование не гшла. Так, например, в селе Новая Мышь Ново-Мышской волости 200 человек избирателей в голосовании участия не принимало, а некоторые из них, которые прихо.дили на избирательный участок, зачеркивали бюллетени. Всего было зачеркнуто по Новой Мыши 200 бюллетеней. Бывший жандарм Военного Жандармского управления Запруцкий Генрих получил бюллетень и заявил, что за большевистских кандидатов голосовать не будет. Заявил во всеуслышание.

В Даревской волости - деревня Литва и др. деревни, которые 
расположкены вблизи костела и проживания ксендза. В 8 часов утра на избирательном участке кроме председателя и 2 -х членов комиссии никого не было. На вопрос, почему же у Вас на участке никого нет из избирателей, председатель участковой комиссии ответил: „Наше население раныпе пойдет в костел помолиться Богу, а потом придет на голосование». Когда в костеле собралось население, то ксендз заявил: «Сегодня богомоление будет сокращено, так как сегодня выборы. Идите все на голосование и голосуйте за национальное отечество».

IIo 4-му избирательному округу на 5-м участке на место бюллетеней опушено было около полтора десятка чистой бумажки. На одной из них была надпись: «Бей зкидов, спасай Россию».

IІо 7-му избирательному округу в городе были зачеркнуты несколько бюллетеней, и были надписи: «Еше Польша не згинела», «Ла здравствует пан Мостицкий».

Больше фактами отрицательных примеров мы не располагаем.

В настояшее время вся работа партийных и комсомольских организаций переключена на разьяснение решения Народного Национального Собрания, решения Пятой Внеочередной Сессии Верховного Совета СССР, Доклада тов. Молотова на Сессии и на подготовку к проведению 22-й годовщины Великой Октябрьской Социалистической революции.

IIо проведению праздника создана комиссия при Временном Управлении, во все волости посланы докладчики, для докладчиков проведен инструктивный доклад. 5-го, 6-го в уездах будут проводиться торэкественные заседания Волостных и Сельских Крестьянских Комитетов. В городе 6-го-торжественное заседание Временного Управления с участием рабочих, интеллигенции и воинских частей, после доклада будет художественная часть. 7-го числа будет в городе и в селах демонстрация. 8-го по всем школам будут проведены детские митинги. Временным Управлением отпущены средства для школ, для учеников закупағотся подарки. Часть подарков получена из Советского Союза: книги, альбомы, портреты напих вождей, руководителей партии и правительства, напих героев, учебники и наглядные пособия, письма от учеников Советского Союза.

Уполномоченный ШК КІІ(б)Б по организации партработы по Барановическому уезду (podpis) Денисевич 
Oryginal, maszynopis.

Źródło: PAOB w Brześciu, zesp. 7580 „P”, spr. 1, t. 27, k. 30-31.

a Wielkie litery i podkreślenia oryginału.

\title{
Dokument 18
}

1939 listopad 5, Minss, - Sprawozdanie aktywisty skierowanego przez $K C K P(b) B$ do Grodna do pracy agitacyjnej w kampanii wyborczej do Zgromadzenia Ludowego Zachodniej Biatorusi.

\author{
ШК КП(б)Б $\mathrm{Б}^{\mathrm{a}}$ \\ Отдел пропаганды и агитации
}

\section{ДОКЛАДНАЯ ЗАПИСКА}

В период подготовки и проведения выборов в Народное Собрание Западной Белоруссии ШК КП(б)Б 12/X я был послан на агитационную работу в город Гродно. $13 / \mathrm{X}$ вечером напіа гродненская группа агитаторов в числе 9-ти человек приехала на мес-

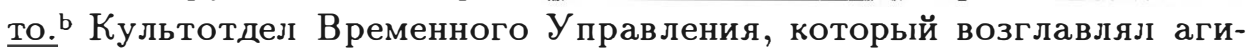
тационную работу, оставил меня для агитработы в городе. С начала культотдел Временного Управления города Гродно и Гродненского уезда руководил работой агитаторов, работаюцих в городе и волостях. Шрактика и первый опыт агитационной работы показали, что город необходимо выделить от уезда и что в городе необходимо создать центр агитационно-массовой работы. Таким центром явился созданный 14-15 октября культотдел Временного Управления города. Его возглавил тов. Гуревич.

Как были расставлены на работе агитаторы. Основная масса агитаторов, армейских, из местного населения и агитаторов присланных ШК КП(б)Б, была закреплена на работе на определенных избирательных участках. Группа товарищей в числе 4-х человек, и я в том числе, работала при культотделе по обслуживанию массовых собраний избирателей.

По поручению культотдела Временного Управления я выступал с докладами на тему: «Победа социализма в СССР и выборы 
в Народное Собрание Западной Белоруссии» на массовых собраниях и митингах избирателей.

$14 / \mathrm{X}$ - доклад на собрании рабочих и служащих почты и телеграфа города. ІІрисутствовало около 200 человек.

$16 / \mathrm{X}$ - доклад в Доме Красной Армии на собрании избирателей 1-го избирательного округа. ІІрисутствовало около 500 человек. $\underline{\mathrm{B}}^{-}$ ступило 7 человек. На этом же собрании состоялась первая встреча кандидата в депутаты Народного Собрания Западной Белоруссии с избирателями.

$18 / \mathrm{X}$ - доклад на собрании избирателей 6-го избирательного округа. ІІрисутствовало 450 человек. На собрании состоялась встреча депутатов с избирателями. Выступило 4 товарища.

$20 / \mathrm{X}$ - доклад на собрании избирателей 11-го избирательного округа. ІІрисутствовало 1200-1500 человек. Выступило 6 человек.

$21 / \mathrm{X}$ - выступление на митинге избирателей 9-го избирательного округа.

Таким образом, организованным путем мною обслуљкено свыше 2000 человек избирателей.

Все массовые собрания и митинги избирателей прошли с больпाим политическим по,цемем. Выступающие избиратели на собраниях выражали любовь и преданность освобожденного народа к партии Јенина-Сталина, любовь и преданность вождю народов товарищу Сталину, нашей родной Рабоче-Крестьянской Красной Армии.

ІІожилой рабочий кожевенного завода на массовом собрании избирателей 1-го избирательного округа 16 октября говорил:

«Мы, группа рабочих (4 человека), с затаенным дыханием слушали выступление по радио 17 сентября главы советского правительства товарища Молотова. Слезы радости и счастья появились у нас на глазах, когда мы услышали, что советское правительство протянуло нам руку братской помощи.

Мы, рабочие, знали, что так же, как солнце восходит с востока, с востока же к нам придет помощь великого советского народа. За оказанную помощь, за освобождение трудящихся Западной Белюруссии от гнета помещиков и капиталистов мы благодарим Краснуго Армию, мы благодцарим великого, любимого Сталина».

На всех собраниях, митингах трудлщиеся с чувством величайшей радости отмечают, что кончилось то копмарное 20-летие, когда польские помещики и капиталисты угнетали трудлщихся Западной Белоруссии и Западной Украины, кончились годы голода и холода, 
годы ницеты и безработицы, годы бесправия и национальной розни.

На собрании-митинге избирателей 11-го избирательного округа, на котором присутствовало до 1500 человек, 21 октября выступивІІий рабочий разоблачал контрреволюционные разговоры скрытых врагов народа о том, что придет черная армия, и что спасен будет тот, кто выставит у окон матку боску. Әтот рабочий призывал избирателей не верить в распространяемую скрытыми врагами народа ложь, и говорил о силе, могуществе и непобедимости Рабоче-Крестьянской Красной Армии и призывал избирателей единогласно голосовать за выставленного кан,ди,дата в депутаты Народного Собрания.

Рост политической активности тру,дяцихся Гро.дно сопровождается производственным подъемом. Готовясь к историческому Наро,дному Собранию, рабочие добились значительного увеличения производства продукции. Колэлектив рабочих фанерной фабрики «Дыкт» за неделю до выборов в Наро,дное Собрание увеличил произво.дство фанеры на 43 проц. У величили также выпуск продукции рабочие велосипедного завода «Неман» и других предіриятий города. ${ }^{c}$

Тру.дяциеся Гро.дно с болыпим под'ьемом приняли участие в выборах депутатов Народного Собрания Западной Белоруссии. Например, во втором избирательном участке 5-го округа 3 члена комиссии не управлялись выдавать избирателям избирательные бюлюетени. К 10-ти часам утра здесь проголосовало более половины избирателей.

Закс-Вольф пришел для голосования вместе с женой и тремя сыновьями. При чем он с гордостью заявил, что скоро своих трех сыновей от.даст в Красную Армию.

После проведения выборов в Народное Собрание агитаторы провели беседы о XXII годовццине Октябрьской революции. По этому вопросу для актива города и агитаторов 27 октября мною был прочтен инструктивный доклад.

Заметен больпой спрос на советскую и политическую литературу и советские песни. Открытый недавно книжный магазин этот спрос не удовлетворяет. Необходимо увеличить завоз политической, художественной литературы и советских песен в Западную Белоруссию.

5/XI.39 г. ${ }^{d}$

(podpis nieczytelny) 
Oryginał, maszynopis.

Źródło: NARB w Mińsku, zesp. 4, spr. 27, t. 69, k. 226-228.

a Duże litery oryginału.

b Podkreślenia odręczne w trakcie czyțania.

c Akapit zaznaczony na lewym marginesie linią pionowa.

d Data wpisana odręcznie.

\section{Dokument 19}

1939 listopad (po 16), (Mińsk), - Sprawozdanie J. A. Wygońca z pobytu $w$ woj. wileńskim $w$ dniach 9.9-16.11 1939 r. $w$ zwiazku $z$ wyborami do Zgromadzenia Ludowego Zachodniej Biatorusi.

В ЩК КП(б)Б.

КОПИЯ. ${ }^{a}$

От члена КП(б)Б ВЫГОНЕI Е. А. работ. в Минтрамвае.

Отчет по командировке в Западную Белоруссию.

На основании Вашего поручения и командировки от $8 / \mathrm{X}-39$ г. я выехал в г. Вильно. 9/X-39 г. я прибыл в г. Вильно в 11 ч. 30 м. Явился к уполномоченному ШК т. Бойкачеву и председателю Временного управления г. Вильно и области т. Желянину. Я с еще тремя товарицахи получил распоряжение выехать в распоряжение Временного управления г. Поставы и уезда. В ночь с $9 / 10 / \mathrm{X}-39$ г. мы прибыли в Поставы. (уездный центр). В Поставах председатель временного управления т. Бриков созвал совещание прибывших товарищей, на котором ознакомил подробно нас с услювиями работы в Западной Белоруссии и поставил конкретные задачи по проведению выборов в Народное Собрание. Шо окончании совещания т. Бриков распределил нас по два человека на волость. Меня и т. Рыбака (депутата Верховного Совета БССР) направил в Воропаевскую волость Шоставского уезда. Мы на место приехали 11/X-39 г. 
Кроме нас двух приехавших в волости накануне приехали еще три товариша демобилизованные из ря.дов РККА (т. т. Демидов, Стефанович и член ЛКСМ т. Баразина). Мы в тот же вечер созвали заседание крестьянского комитета, на котором я доложил о плане работы по выборам, одновременно познакомился с напими остальными политработниками. Мне как более подготовленному и опытному по руково,дяцей работе пришлось стать во главе напей „іятерки” и всей волостной работе (в смысле оказания политического влияния во всех участках работы). Мои товарици по работе были дисциплинированными и преданными работниками. В нашей волости было 2 избирательных округа и 15 избирательных участков. Списки избирателей еше не были закончены. Участковые комиссии не подобраны, а также и помеццения для голосования.

12/X-39 г. мы обеспечили окончание составления списков (они составлялись из старых „гминных" списков).. Укомплектовали избирательные комиссии из местного населения. Заместителями председателей окружных избирательных комиссий были два напиих товариша

1. Воропииловском - т. Деми.дов

2. Бельковском - т. Баразна.

В этот же :день $12 / \mathrm{X}$ - мы провели собрания - рабочей гвардии, рабочих железнодорожников, кирпичного завода, лесопильного завода и рабочих стекольного завода и заседание комитета, на которых избрали 45 доверенных для 2 -х избирательных округов.

На собрании рабочей гвардии, где я лично проводил собрание, была хорошо развернута критика каждой кандидатуры, из числа 33 доверенных избрали 32 , одному дали отвод по следуююцей причине. Меня спрашивает один из гвардейцев: „Скажите, вот выдвинутый в доверенные гр. Курилович, он в России был в 1928 г. Может ли он быть в доверенных?". Я тут-же довольно тонко помог им его не избрать. А назавтра я его лично вызвал основательно прошупал и по согласованию я его $20 / \mathrm{X}$ отправил в оперативный отдел. Личность оказалась довольно темной.

Мы прилагали все услия к тому, чтобы возможно точнее выяснить јичности выдвинутых доверенных и нам многое у.далось.

Одновременно намечали и узнавали о предпојғағаемых депутатах в Народное Собрание и $12 / \mathrm{X}$ вечером часов в 9 приехал т. Бриков и мы с ним согласовали выдвижение кандидатов, а в 11 час. вечера мы уже собрали заседание крестьянского комитета и обсу,дили 
одну кандидатуру, это т. Баруса Виктора Андреевича, крестьянина бедняка, имел 2,5 га земли, политзаключенный.

13/Х были созваны собрания рабочей гвардии, железнодорожники и рабочие трех заводов и обсуљкдены обе кандидатуры, по обоим избирательным округам единогласно выдвинуты были нами намеченные кандидаты.

ПТ Воропаевскому избирательному округу: 1. Красовский Анатолий Игнатьевич, крестьянин бедняк, политзаключенный; 2. Барус Виктор Андреевич по Бельковскому избирательному округу.

В этот же день 13/Х я собрал собрание доверенных с выдвинутыми депутатами, на котором также обсудили кандидатов в депутаты и единодунно одобрили кандидатуры.

Вторым вопросом, мы распределили доверенных по избирательным участкам. Одновременно провели инструктивное совешание о задачах доверенлых и полюжение о выборах.

Были утвержденые два ответственных товарища, из числа доверенных за регистрацию депутатов.

$14 / \mathrm{X}$ день регистрации депутатов до 12 час. дня.

$15 / \mathrm{X}$ обеспечили областное совещание председателей и секретарей окружных избирательных комиссий.

16/Х мы распределились по обоим округам и провели 10 митингов, на которых была встреча депутатов с избирателями. Везде единодупно одобряли кандидатов. Превозглапали здравицы товаригу СТАЛИНУ, т. ВОРОШИЛОВУ, т. МОЛОТОВУ и т. КАЛИНИНУ. Все как один говорили, что будем голюсовать в первую очередь за любимого СТАЛИНА.

Начиная с 16/X мы ежедневно проводили по 8-10 митингов с проработкой о выборах в Народное собрание. Мне и моим товарищам приходилось делать по два собрания в один день с проработкой положения по выборам. Во всей волости было 50 деревень кроме хуторов осадников и мы везде провели собрания крестьян и прорабатывали полюжкение о выборах. За время с 11/X до 21/X по Воропаевской волости мы провели 65 собраний и митингов.

Кроме указанных митингов и собраний напи доверенные провели околю ста бесед о положении по выборам в Народное Собрание, чем обеспечили исключительно активное участие в голосовании.

На всех 15 участках были подобраны соответствуюшие помещения и при всей нашей бедности в портретах, плакатах и печатных лозунгах. Мы прекрасно оформили избирательные участки. Сами 
составляли лозунги, устроили кабины, построили арки с зеленью и лозунгами (хотя на бумаге). Круглые ночи совместно с активом писали сами лозунги и вели контроль за другими. Деревенская моло.дежь и актив стариков деятельно готовились ко дню выборов, посыпали дорогу к участкам желтым песком, зеленью. Почти на всех участках были танцы, привлекли местных музыкантов, пели песни.

Ко мне приходили старики и молодежь за песнями, а их у нас не былю. Однако приходилось, что возможно переписать от руки размнољкать и раздавать на участки. Ко мне пришел активист дер. Барейки бедняк т. Мишута и просил ему переписать Интернационалг и они пели на участке в день выборов. А также молодой активист секретарь Кезикского избирательного участка т. Кейзик тоже организовал песни, танцы.

День выборов был превращен в торжество, в подлинно народный праздник. На участках Кезика, Гольбин, Бельках, Войцехах и многих других голосовать ІІли организованно - колоннами со знаменами и јозунгами, с песнями и музыкой.

В Голбейский избирательный участок Воропаевского округа приплла голосовать колонна, во главе которой пाел рабочий стекольного завода Драгун Антон 73 лет с гармопюкой в руках и он говорит - я еще никогда не чувствовал себя так молодо, счастливо, как сегодня. Мы выражаем своғо люобовь к советской власти и дорогому СТАЛИНУ. На одном из митингов старик дер. Трумничи т. Нестерович Игнатий 81 год, выступил со слезами на глазах и рассказал как над ним издевались пганы. Что он за 4 веника нарезанных в лесу пана Пшездецкого получил в своем возрасте 7 суток карцера и далее говорит - я за 81 год теперь только свободно вздохнул. Нет больпе возврата таким издевательствам, под руководством нашего друга СТАЛИНА мы будем строить нашу счастливую жизнь.

Можно еще очень много привести ликующих восторжественных речей в честь Красной Армии и наших вождей. Однако как маневр:

1. В день голосования в д. Балаях (избирательный участок) ксендз, когда собрались моляпциеся замкнул костел и предложил всем итти голосовать и в этот день в костеле не служил.

2. В дер. Рымках (избирательный участок), когда мимо церкви прошла колонна избирателей с песнями, то почти все молящиеся щримкнули к демонстрантам и попли голосовать.

Наряду с друзьями народа, вернее с благожелателями советской власти, были классово-вражеские вылазки, как-то числа 15/X 
в Бельковском избирательном округе возле имения Полово нашли разбросанными по дороге 4 листовки БРП (братств русской правды) с привязанными камушками. Мы из этого с,делали себе выводы. Я туда перебросил трех своих товаришей до конца выборов и мобилизовал весь актив, который мы сколотили в округе и выборы обеспечили на отлично.

В день об'ьявления договора нашего с Јитвой, контрреволющионные силы подняли головы. Говоря, что мы с Полыпи уйдем и что надо голосовать за Польшу, за самостоятельную Белоруссию. Но это мы разбили в пух и прах. Большевистские методы борьбы оказались на высоте полюжения. Мы не имели по волости ни одного голоса.против депутатов и только по обоим округам по 15 участкам имели испорченными около 60 бюллетеней.

По Бельковскому избирательному округу результат голосования $-99,3 \%$.

По Воропаевскому избирательному округу:

Кезикский изб. участок $100 \%$

$\begin{array}{lll}\text { Голбейский } & \text {-"- } & 98,7 \% \\ \text { Войцехи } & - \text {-- } & 99,3 \% \\ \text { Анкуды } & - \text {-- } & 97 \%\end{array}$

и т. д.

В день выборов я лично об'ьехал 7 избирательных участков где останавливаясь собравнимся читал газеты, раз'яянял ря,д вопросов, ни на одном участке не было никаких выступлений против выборов, несмотря на то, что в ряде деревень делают самогон, пьянства в этот день не было.

Осадники и другие отбросы общества приходл голюсовать не хотели заходить в кабины, чтобы не дать повода к подозрению их отношения к советской власти. Все это нами учитывалось.

Исходя из изложенного можно заключить, что выборы прошли успешно.

После выборов прибывших со мною трех товаришей в Поставы отпустили домой. А меня задержали до 16/XI-39 г.

За период моего пребывания в волости я кроме агит-массовой работы по выборам проделал огромную работу по организационной и оперативной работе в волюсти. Много при помоши моих товарищей и местного населения из'ьто и передано в оперативный отдел НКВД г. Поставы около 18 чел. белогвардейцев, осадников, провокаторов и ппиионов. 
Я столкнулся с таким фактом, что на лесопильном заводе (который стоял) был избран заводской комитет во главе которого был избран бывший управляющий этого завода. Я этот комитет переизбрал на широком рабочем собрании, где была прекрасно развернута критика и самокритика. Завод отремонтировали, но не быјо сырья. Крестьяне заняты вывозкой и рубкой леса для себя не хотели работать для заво.ца. Я собрал собрание рабочих, организовал бригады по рубке.леса, а потом собрал собрание крестьян, которые выпли тоже в лес и приступили к вывозке его, после чего $28 / \mathrm{X}-39$ г. завод пушен.

Далее обеспечил хлебоснабжение населения. Арендаторы мельниц не хотели ремонтировать мельниц, желая видимо постепенно амортизировать их и оставить. Я их вызвал и дал.срок для ремонта и в мою бытность они приступили к ремонту их. И целый ря,д других работ мною проделано.

Политико-моральное состояние основного населения исключительно прекрасное; выражают горячую любовь к советской власти и ее лю,цям, особенно к бойцам Красной Армии.

По вопросу снабжения населения солью, керосином, спичками и табаком дело поставлено из рук вон плохо. Мне за все время удалось получить только 6 тонн соли, 50 литров керосина (к выборам) и 300 кгр. махорки. И это вызывает некоторое недовольство населения. Кроме того население настоятельно требует открытия пाкол на русском языке, учебников нет, преподавателей нет и меня очень просили эти вопросы срочно разрешить. $Я$ лично прошу обратить самое серьезное внимание на эти первостепенные не.достатки и их скорее ликвидировать.

Мною изложено основное, еще ря.д повседневных жизненых вопросов мною разрегенных я не изложил з.цесь, при на,цобности изложу устно.

(подпись) ВЫГОНЕП.

B E P H O:

Kopia, maszynopis.

Źródło: NARB w Mińsku, zesp. 4, spr. 27, t. 69, k. 194-201.

a Wielkie litery i podkreślenie w tym miejscu oryginału.

b Podkreślenia w tym miejscu i w innych w tekście dokonane w trakcie czytania.

c Ten akapit zaznaczony na lewym marginesie pionową linia. 


\section{Dokument 20}

1939 listopad 19, Brześć, - Raport instruktora KC KP(b)B o stanie przygotowań do uyborów do Zgromadzenia Ludowego Zachodniej Biatorusi w województwie poleskim.

СЕКРЕТАРЮ IIK КІ(б)Б

TOB.

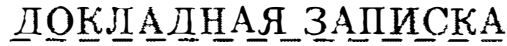

О СОСТОЯНИИ ПОДГОТОВКИ К ВЫБОРАМ

В БЕЛОРУССКОЕ НАРОЛНОЕ СОБРАНИЕ ПО ПОЛЕССКОЙ ОБЛАСТИ.

Подготовка к выборам в Белорусское Народное собрание по Полесской Области проходит неудовлетворительно. До сего времени во многих местах не созданы избирательные участки (Высоколитовск участок № 3 , местехко Черновичи участок № 4 и т. д.). Нет заготовленных избирательных урн и кабин. Избирательные бюллетени по некоторым уездам на 19 / Х - не отпечатаны (Кохово и др.).

Совершенно отсутствует информация. Областное управление не знает, что делается на местах, сведения не концентрируются, документов так-же нет. Особенно нет сведений о политико-моральном настроении населения. Между тем, по области имеюося факты контрреволюционной деятельности враждебных әлементов. Например, в Высоколитовском уезде в деревне Чепелевичи группа провокаторов (конфидентов) состоящя из Ан,дросюка Кандратия Михайловича бывший староста (Солтәс), Габрущука Данила Яковлевича и Осинского Виктора Адамовича, прводят работу против выборов и против Советской власти. Они разъезжают вооруженные по деревням и раз'ьясняют крестьянам, что „Советская власть здесь не была и не будет, еще будет восстанавливаться Полына. Англия и Франция кончают покорять Германию, потом возьмутся за СССР. Coветы поплатятся за Польшу". Они угрожая предлагағот крестьянам не принимать участия в голосовании. Об их контрреволюционной работе Временный крестьянский комитет деревни Чепелевихи вынес специальное решение. На заседании комитета об этом подтвердили Кузьмин Николай Устинович, Андросюк Арсений Семенович, Капонюк Анцрей Фецорович и другие. 
Протокол заседания комитета подписали 7 человек.

2. Болыпим недостатком считаю то,положение, что при намечении окружных и участковых избирательных комиссий, а также при намечении кандидатов в народное собрание по отдельным уездам Полесской Области не рекомендовано ни о.дного трудящегося Польской национальности. Например в составе окружных комиссий один поляк. В составе участковых комиссий ${ }^{\mathrm{b}}$ поляков: Из числа выдвинутых кандидатов по Брест-Литовскому уез,ду и городу не рекомен,довано ни одного поляка. По Кобриньскому уез,ду ни одного поляка. По Пружанскому уез,ду ни о,дного поляка. По Пинскому. уез,ду и городу из 44 человек, 2 поляка. По.Драгинияевскому уезду из 44 человек, 1 поляк и т. д. ${ }^{\mathrm{s}}$

3. Для обеспечения выполненя выборов $18 / \mathrm{X}-39$ г. состоялось совещание областного Временного Управления на котором намечены практические мероприятия.

19./X-39 г. посланы в уезды ответственные товарищи из числа руководящих работников областных отделов для руководства выборами и оказания помощи на местах. Налажен сбор информаций и учет информационных материалов. Улучпाено делопрозводства по выборам.

4. Необходимо разрепить вопрс о присоединение к Украинской Советской Республике населения Камень-Капирского уезда, где проживают болынинство украинцев и население на всех собраниях выдвигает вопрос о присоединени к Советской Уккраине.

5. При ознакомлении с работой по подготовке к выборам в ғ. Семятич установил следующее:

Временное Упавление города образовалось самостоятельно из числа не надежных людей, Например предсседатель КАРПЮК и секретарь ДОЛИНСКИЙ имеюо более как по 20-десятин земли: ФУРГЕЛЬ зав. промыпленным отделом поддерживал: и поддерживает связи с ППС. ЗАГУБИЕНЬ член комитета был осужден на 6 лет за воровство. Другие члены комитета и зав. отделами тоже такие-же лица. Поэтому не случайно они до последнего, времени не разрепали крестьянам делить помещичьи земли и обеспечили: оставшихся помещиц.

В настоящее время ве.цут работу против выборов. Дело было так; до приезда товарищей посланных в Белосток в помощь по выборам члены Временного Управления гор. Семятич сами себя выставили кан,ди,датами для голосования в депутаты Народного Собрания 
Radzieckie dokurnenty o przygotowaniach do wyborów do Zgromadzenia Ludowego... 339

и распределили по округам.

Прибывпияе товарици ознакомивпиись с выставленными кандицатами поставији на заседании Временного Управления вопрос о выставлении новых кандидатов и снятия выставленных. Временное Управление с этим предложением не согласилось, заседание прополжалюось всю ночь в конце, концов его нриллось закрыть. После этого прибывпияе товариши разоплись по фабрикам и крестьянским комитетам, провели собрания и выставили новых кандидатов. Что-бы сорвать голосование за выставленных, вполне достойных кандидатов, члены Временного Управления ездят по фабрикам и проводят агитацию против этих кандидатов. Например про т. П̈РОКОПЮКА они раз'ьясняғот рабочим, что он старик (ему 65 лет) и ничего не соображает, не сможет сказать слова в народном собрании и отстоять автономию (как видно эти лица имеюот ввиду выдвинуть лозунг о создании автономной Западной Белорусской Республики). Секретарь ДОЛИНСКИЙ на собрании заявил, что лучше для населения будет если для Западной Белоруссии будет предоставлена автономия.

Плохо помог присланным товаришам прибывплй из города Бельска т. ХОТЬКО, он назначил собрание председателей и секретарей участковых комиссий, никому об этом собрании не сказал и уехал. В результате это собрание пришлось проводить прибывішим товарищем. В это время члены В ременного Управления разьехались по деревням и началии проводить собрание крестьян. ДОЛИНСКИЙ - деревне Велико-Мошена собрал стариков и начал ругать зачем цопустили пересматривать кандидатов, я вам говорил, что нужно голосовать за меня и КАРІЮКА. Такие собрания были проведены ими и в других местах. Когда население с ними не согласилось, то, чтобы сорвать выборы они начали подбирать компроментирубщий материал на кандидатов. При этом прилагаю заявление одного члена комитета на кандидата т. СОЛЮНИКА.

Обрашағо ваше внимание на то, что во Временном Управлении

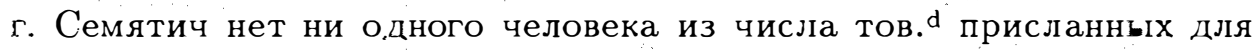
работы в Западную Велоруссию. Присланные товарищи ФАРАФОНОВ, СИМОНОВ, ПОДОЛЯК и другие работаюо только по выборам. Они задержали 20 человек пытавшихся перейти границу в числе котюрых были 2: офицера. У одного осадника задержали спрятанную помециком автомапину, но они мало работаюо по наведению болышевистского порядка во Временном Управлении. 
Кроме этого эти люди сидят по 2-3 недели без денег и очень нуждаюются.

ІІрщшу дать указание Бельскому Временному Управлению оказать товарищам помощь в работе предоставить им болыпе инициативы по наведению порядков во Временном Управлении.

О выпеизложенном довожу до Вашего сведения для принятия мер.

Брест-Јитовск

ИНСТРУКТОР ІІК КП(б)Б (podpis) (КУРОВ)

19 ноября 1939 г.

Oryginał, maszynopis.

Źródło: NARB w Mińsku, zesp. 4, spr. 5, t. 2113, k. 4-8.

a Wielkie litery i podkreślenie oryginału.

b Po tym słowie wolne miejsce na wpisanie liczby Polaków.

c Słowa „z 44 osób 1 Polak” podkreślone w trakcie czytania.

d Słowa „z liczby tow.” wpisane odręcznie.

\section{Dokument 21}

1939 listopad 22, Mińsk, - Notatka instruktora $K C K P(b) B$ Kurowa o pracy masowo-agitacyjnej podczas kampanii wyborczej delegatów do Zgromadzenia Ludowego Zachodniej Biatorusi.

СЕКРЕТАРЮ IIK КII(б)Б тов. Малину

$\mathrm{C} \Pi \mathrm{P} \mathrm{A} \mathrm{B} \mathrm{K} \mathrm{A}$

О проведенной агитмассовой работе в компании по выборам депутатов в Народное Собрание Западной Белоруссии ${ }^{\mathrm{b}}$

Агитационно-массовая работа в Западной Белоруссии среди населения началась с момента вступления Красной армии на территорию бывшего польского государства. Наши советские танки, самолеты, дисциплинированность бойцов и командиров, хорошее состояние явились лучшим наглядным агитационным материалом, который 
разбил вдребезги всю польскую гнилую пропаганду и агитациғо о том, что в Советском Союзе люди ходят голые и босые, армия слабая, танки фанерные и картонные, что в Советском Союзе нечем воевать и другие нелешые брехни о трудящихся и советской армии. Трудящиеся Западной Белоруссии наглядно убедились в силе и могуществе страны социализма. В деревне Беницы, Молодечинского уезда один крестьянин на собрании заявил: «Мы теперь видим, что танки настояшие, все советские солдаты одеты несравненно лучпе, чем польские солдаты; все панские разговоры о том, что танки фанерные, а народ ходит босый - хлустня». В 1 избирательном округе JІемешевичской волости Пинского уезда на собрании крестьяне с удивлением смотрели на наших агитаторов и заявляли: «Не верится нам, что Вы из Советского Союза. Вы такие здоровые, полные, веселые и очень хорошо обуты и одеты». Когда их убедили, что әто советские люди, то все выступағошие на собрании заявили: «Вот подлые паны, все время нам говорили, что в СССР люди худые, кушают друг друга, ходят босые и т.д., а тут получается наоборот".

Размах агитационно-массовой работы в Западной Белоруссии был очень велик. Каждый боец, каждый командир и политработник являлись агитаторами и пропагандистами и с большой охотой проводили беседы с крестьянами, рабочими и интеллигенцией, детьми и пюкольниками о жизни трудяшихся в СССР, о напиих совхозах, колхозах, промышленности, о партии и о вожде трудящихся товарише Сталине. Трудно сказать, сколько было проведено бесед, сколько человек проводило беседыс. Коли учесть тот огромный интерес населения к беседам, и то, что каждый боец, командир и политработник охотно раз'ьясняли населению об успехах трудяцихся СССР, то смело можно сказать, что все плть трудовых миллионов населения Западной Белоруссии были охвачены агитмассовой работой в первые 5-10 дней пребывания Красной Армии на территории бывшего польского государства.

Особенно пाироко и организованно начала проводиться агитмассовая работа после создания в ременных управлений и крестьянских комитетов, после присылки уполномоченных IIK КII(б)Б по организации партийной работы и в кампанию по выборам депутатов в Народное Собрание Западной Белоруссии.

До началга избирательной кампании для развертывания агитационной массовой работы среди населения и демонстрации в насе- 
ленных пунктах советских кинофильмов отделом пропаганды и агитации ШК КП(б)Б были посланы 12 автомашин, разработан: для них маршрут обслуживания населенных пунктов. По.добраны были пропагандисты и агитаторы в количестве 18 чел.; киномеханики и шоферы в количестве 24 челов. Машины выехали с работниками Минска 24.IX-39 г. и пробыли до 1.X. За это время автомашинами пропупено 700 киносеансов, которыми обслужено 216 тысяч населения. Проведено агитаторами 920 бесед, митингов и докладов, на которых присутствовало 168 тысяч человек. Беседы, митинги и доклады проводились на разные темы: о жизни трудяцихся СССР и БССР, обсуждались кинокартины, об избирательной кинокампании, о кандидатах и дружбе народов Советского Союза, демонстрировались лучпие кинокартины: «Ленин в 18 году», «Честь», «Великое зарево», «Тринадцать» и т.д. В м. Гайловка после просмотра кинофильма девочка 15-ти лет, дочь рабочего Прокоповича, которая не имела возможности учиться при панах, заплакала от радости, когда увидела советских летчиц, и громко заявила: «Я теперь стану также летчицей».

Характерно отметить то, что автоагитмапины в болынинстве обслуживали такие места, где были жители, которые никогда не видели автомобиля, а о кино совершенно не имели представления. Когда они просмотрели напи картины, они были очень поражены достижениями науки и техники и благодарили партию и правительство за заботу о них.

Кроме проведения бесе.д, докладов, демонстрации кинокартин агитаторы распространили большое количество литературы, газет, лозунгов, плакатов, портретов и фотокарточек руководителей партии и правительства, всего около 70.000 экз.

C 20 сентября по 4 ноября с.г. отдел пропаганды и агитации ШК партии периодически посылал в Западную Белоруссию библиотеки, массовую литературу, плакаты и лозунги.

За это время было послано:

портретов руководителей партии и правительства - $\underline{96.008}$ плакатов разных лозунгов и листовок учебников истории ВКП(б) (краткий курс) $\underline{4.000 .000}$ конституции СССР и БССР порядок выборов в Народное Собрание Западной Белоруссии 
Radzieckie dokumenty o przygotowaniach do wyborów do Zgromadzenia Ludowego... 343

уставов ВКП(б) - 는

произведений классиков марксизма, не считая книг, посланных с библиотеками

библиотек (с количеством книг 69.644)

- $\quad \underline{1.304}$

массовой литературы о стахановцах, сельском

хозяйстве и др.

разной ху,дожественной литературы

нот и советских песен

фотографий города Минска

нагру,дных значков

$-\quad \underline{900.000}$

$-\quad \underline{52.334}$

$\underline{2.208}$

- 372 альбома

государственных гербов союоных республик и СССР $\underline{1.119}$

патефонов

пјгастинок

$-$

учебников для школ

и большое количество мето,дических и учебных нагля,дных пособий.

Для.я гостей и членов Полномочной Комиссии Народного Собрания Западной Белоруссии было роздано 186 библиотечек. Торгующие организации Когиз и Военторг продали люзунгов, плакатов и портретов около 100 тысяч экземпл., больное количество учебников Истории партии, произведений классиков марксизма и другой литературы.

В перио,д избирательной кампании по выборам в Наро,дное Собрание Западной Белоруссии отделом пропаганды и агитации было послано 4 агитбригады в количестве 150 агитаторов. Агитбрига,дами была проведена болыная агитационно-массовая работа, оказана помоць временным управлениям по организации крестьянских комитетов, пуску в ход предприятий, по выявлению контрреволюционных элементов, налаживанию нормальной жизни в местечках и городах, выявлению и привлечению для проведения агитмассовой работы актива из числа местного населения.

Обкомы и Минский горком КП(б)Б по предложению ЦК взяли шефство над областями Западной Белоруссии на предмет оказания практической помоци в проведении агитмассовой работы в период избирательной кампании. Для этой цели было послано на $\underline{10 \text { дней }}$ 400 челг. агитаторов из числа ответственных работников областного актива. Всего по Западной Белоруссии работало в окружных и участковых избирательных комиссиях на избирательных участках более 40 тыс.яч агитаторов. Местное население охотно принимало участие в агитмассовой работе, особенно бывшие политзаключенные, интел- 
лигенция (врачи, учителя, конторгцики) и комсомольцы.

Агитмассовая работа проводилась в форме бесед с населением по вопросам о жизни трудяцихся СССР, Сталинской Конституции, пре,цстоящих выборах, национальной политике и т.п., вечеров вопросов и ответов, митингов, встреч кандидатов с избирателями на избирательных участках и политзаключенных с населением. На избирательных участках прорабатывался порядок о выборах с избирателями. Читались лекции, проводились собрания по предприятиям, массовые митинги с избирателями в кинотеатрах, с демонстрацией кинокартин, выступления бывпгих политзаключенных о тюремных застенках бывшей Полыпи. Посланные агитаторы проводили инструктивные беседы с агитаторами местного населения, собрания с членами участковых комиссий и собрания молодежи по пाколам и гимназиям.

Каждый агитатор за время своей работы провел не менее как 15-20 бесед, собраний, митингов и др. Таким образом, по Западной Белоруссии было проведено бесед, докладов, митингов и собраний 620 тысяч, которыми охвачено 13 миллионов человек, это значит, что каждый избиратель присутствовал на 3-4 собраниях, бесе.дах и митингах.

Отзывы о проделанной агитаторами работе - самые лучшие. Население осталось довольно. Почти везде можно было слыпать, что только с приходом Красной Армии в течение нескольких дней мы узнали, что делается на свете, узнали больше, чем за 20 лет по.д гнетом панов.

Интересно отметить такой случай. В деревне Перешир агитатор т. Каровой провел собрание стариков и старух. После докла,да один из стариков задает вопрос: «Скажите, т. комиссар, правда ли, что у Вас стариков топят на мыло? И, как видно, им никто не помогает, т.к. в Конституции также написано: кто не работает, тот не ест». После того, как им разъяснили этот вопрос, они остались очень довольны и не знали, как выругать и вылить свою злобу панским агитаторам. - «Мы очень благодарны товарицу Сталину за наше освобождение» .

День выборов в Наро.дное Собрание явилгся по.цлинно массовым праздником освобожденного народа. Избирательные участки были тщательно убраны и украшены портретами руководителей партии и правительства, лозунгами, плакатами и зеленыо. В деревнях дорожки к избирательным участкам были обсажены деревьями и посы- 
паны белым песком. Почти во всех деревнях были построены арки, которые были красиво разукрашены. Население было само заинтересовано как можно лучще и красивее оформить свой участок. Это было просто соревнование народа на лучшее оформление участка и проведение выборов. Народ в день голосования не знал, как выразить свою преданность Советской власти. Восторгу населения не былю предела. 75-люетний Наум Романюк, когда ему указали зайти в кабину, заявил в присутствии избирателей: «Я 20 лет ждал Советской власти, теперь буду за нее голосовать открыто, к этому призываю всех избирателей». Гтодыкинский избирательный участок Кобринского уезда. Молодежь веселилась, танцевалг, играла и пела советские песни; с ними вместе веселились старики. Население заявляло, что поляки не давали собираться для гулянья, теперь они чувствуют себя' свободно.

До выборов под руководством агитаторов создавались хоровые и музыкальные кружки, разучивались советские песни и танцы, мобилизовывались гармопки, баяны и скрипки. В день выборов народ веселился, молодељь устраивала танцы, игры и хороводы.

В Голбейском избирательном участке Воропаевского округа Постовского уезда рабочий стекольного завода Iрагун Антон, 73 лет, с гармопкой в руках привел организованно колонну избирателей для голосования. Прибывши на участок, заявил: «Я никогда не чувствовал себя так молодо, весело и счастливо, как сегодня. Мы все выражаем свою любовь к Советской власти, к дорогому Сталину». Интерес к выборам и массовым мероприятиям был настолько силен, что в некоторых местах поборол укоренивпиеся религиозные предрассудки. Например, в Кобрине около одного избирательного участка, находившегося напротив церкви, в день выборов молодељкь с утра устроила танцы и игры. Население в этот день в церковь не пошло, а все приняли участие в народном гулянии. В результате поп закрыл церковь, и церковные богослужения не состоялись.

В г. Белостоке на избирательном округе № 2 произопла трогательная сцена. $65 \%$ избирателей в округе составляли поляки. В день выборов в 4 часа 15 мин. утра явилась на избирательный участок одна старушка. Получив бюллетень первой, подойдя к урне со слезами на глазах, подняла его высоко и воскликнула: «Нех жыве Сталин». Опустив бюолюетень, расплакалась как дитя и заявила: «Детки, я ІІлачу от великого счастья, что дољкила до такого светлого дня».

Массовые мероприятия, особенно советские песни, на многих 
стариков произвели сильное впечатление. В деревне Черницы Брест- Литовского уезда около избирательного участка выступал организованный из местной. моло.дежи хор. Когда он исполнял «Катюшу» и «По долинам и по взгорьям», то многие старики плакали. Когда их спросили, почему они плачут, - ответили: «Как же, детки, не плакать, ведь это наша русская; родная песня, которой не слыхали более 20 лет».

Во время проведения агитмассовой работы использовался местный материал. Например, агитатор т. Раввин, проводя беседы, выяснил: если у крестьянина имеется зажигалка, он должен уплатить злотый за то, чтобы на нее поставили печать; если у крестьянина жандармы находили зажигалку без печати, то накладывали штраф 15 злотых или 3 месяца тюрьмы; для того, чтобы поступить в школу, нужно принять католическую веру. Это было использовано им в его агитационной работе в качестве примеров издевательства над белорусским наро,дом и имело болыное агитационное значение.

В деревне Трумничи Поставского уез,да-на одном митинге 82-летний старик Нестерович Игнат выступил со слезами на глазах и рассказал, как над ним издевались паны: за 4 веника нарезанных в лесу пана Гжездецкого отсидел 7 дней в карцере - «Только теперь мы вздохнули свобо,дно». Его речь так растрогала присутствуюгцих, что многие плакали.

Т. Рольник приводил примеры, имевшие место в дер. Крестыбиловичи Пинского уез,да. Там учитель запрягал детей в повозку и на них разъезжал по деревне. В дер. Черзово-Первое крестьянин Белоус Роман, выступая на митинге, рассказал присутствуюгцим о том, как на том месте, где проводилось собрание, поляки устроили линчевание десяти белорусских крестьян; а потом их зверски убили. Во время его выступления все поснимали шапки и почтили память погибших братьев.

После окончания работы комиссии для членов и актива был устроен обед у бывшего арендатора панского имения пана Яницкого. Сам Яницкий в качестве официанта неуклюже ухаживал за членами комиссии. Когда ухо,дили, то председатель комиссии т. Стефанович сказал: «Месяца два назад Яницкий не стал бы с нами разговаривать, а теперь как заискиваююций за нами ухаживал. Мне 73 го.да, я только теперь имел большое удовольствие, потому что больне 60 лет гнул спину на пана, а сегодня пан за мной ухаживал. Настала для нас счастливая пора». 
В г. Воложине на одном собрании начальник жкелезнодорожной станции иронически задал докладчику такой вопрос: «Имеются ли в СССР такие красивые пуговицы, как у меня?» Ответить на этот вопрос вызвался 65-летний крестьянин бедняк. Он сказал: «Пуговиц в Полыпе красивых было много, но зато танков не было. В СССР может быть пуговицы похуже, зато танки и самолеты такие, какие никогда не снились напим панам».

В г. Белостоке на 4 избирательном участке один рабочий поляк, бывпиий в Советском Союзе в плену, возвратилгя из-под г. Горьки за 2 дня до выборов. Сойдя с поезда, он направился на избирательный участок, попросил подробно рассказать о выборах и занести его в списки избирателей. На участке просидел несколько часов, рассказывал приходивпиим избирателям о Советском Союзе, об отношении к пленным солдатам и т.д. Жена от знакомых узнала, что муж приехал домой и сидит на участке, быстро прибељкала туда, и на участке произопла радостная встреча; потом сама начала помогать ему в объяснениях и так просидела с ним еце часа 3 ; и уже поздно вечером упіли с участка домой.

Јюди десятками приходили на избирательные участки и предлагали свои услуги: одни - по составлению и переписыванию списков, другие - по изготовлению лозунгов, плакатов, третьи приносили мебель и цветы, четвертые - предлагали свои услуги в качестве агитаторов. На одном только избирательном округе № 19 г. Белостока работало 59 агитаторов и жители местного населения, среди них 10 женцин. Јучіпими и способными агитаторами были:

т. Вильчинский - рабочий-мелаллист, поляк

т. Суражский - рабочий-гіофер, еврей

т. Сидорович - работница-текстил., русская

Используя местный материл, привлекая население к проведению агитационной работы, разъясняя о Советском Союзе, Коммунистической партии и вожде народов товарище Сталине, напи агитаторы проделали громаднейпуюо работу, которая открыла глаза 5-ти миллиионому населению Западной Белоруссии и они увидели свое счастье, свою радостную жизнь в семье трудяцихся великого Советского Союза.

В период избирательной кампании враги Советской власти, находивпгиеся все время под влиянием обещанных гарантий от Англии и Франции, проводили контрреволюционную работу, распространяя среди населения слухи о том, что английские и французские 
войска заняли половину Германии и идут на помоць Полыпе: «Черные войска союзников восстановят польское государство, поэтому не голосуйте за Советскую власть». Эти слухи были распространены по всей Запа,дной Белоруссии. Кроме этого, срывали со стен лозунги и плакаты или замазывали их красками (третий участок 19 округа, г. Белосток). Соверпіались нападения на членов участковых комиссий. Например, на т.т. Елина и Андрейчука в Белостоке: Соверпили убийство зам.председателя участковой комиссии т. Гречко в. Дорогиченском уезде. Пытались протацить в качестве члена участковой комиссии на втором участке 19 округа г. Белостока племянника врага народа Егорова - Сабишука Вла,димира, на другом участке - сына вице-прези.дента города, изъятого органами НКВД. На Хи,дровском избирательном участке Кобринского уез,да секретарем комиссии был избран крестьянским комитетом проповедник секты баптистов, учивпийся 4 года в Англии на проповедника. Крестьяне нашему агитатору т. Волохновичу заявили, что они не доверяют этому проповеднику и просят вывести его из состава комиссии - так было и сделано. В Верхолевском избирательном участке Кобринского уез,да в крестьянский комитет и актив участковой комиссии пробрались кулаки. Ког,да там стали вы,двигать кан,ди,дата в Наро.цное Собрание, то этот комитет был против выставленной кан,дидатуры и предложил вы,двинуть своего кандидата. Этим делом заинтересовался т. Волохнович, стал проводить беседу с беднотой и изучать работу комитета; он установил, что в комитете сидят кулаки, которые не приступали к дележу помецичьей и церковной земли, не помогали беднякам в снабжении дровами. На собрании избирателей приплось разоблачить этот комитет, распустить его и выбрать новый.

Нужно отметить, что в ряде мест кулаки принимали активное участие в избирательной кампании с целью приспособиться к новым условиям. На Осинковском избирательном участке Кобринского уез.да с яркой речью за кандидата и за присоединение к Советскому Союзу выступил кулак, имеюгций 80 га земли, 25 коров и др. $\mathrm{Ha}$ Хо,дычинском избирательном участке семья помецика Корсака в полном составе (7 человек) пришла на голосование, не заходя в кабину, открыто голосовала за кан,дидата.

В Бејьковском избирательном округе возле имения Полово были разбросаны листовки «Братства русской правды», призывавшие население воздерживаться от голосования. 
Radzieckie dokumenty o przygotowaniach do wyborów do Zgromadzenia Ludowego... 349

В болыпинстве населенных мест Западной Белоруссии контрреволюционные әлементы распространяли разные слухи о продвижении черных войск Англии и Франции, о скором восстановлении Полыпи и др. Кулацкие элементы пытались приспособиться к новым условиям. Разные партии - сионисты, бундовцы, ппс и др. старались всячески протаскивать свои идеи и выставить своих кандидатов в депутаты Народного Собрания. Все эти попытки и контрреволюционные слухи были разбиты в пух и прах нашими агитаторами. Население помогало в разоблачении контрреволюционных әлементов и их вредной работы. Например, в г. Белостоке на первом избирательном участке выступил т. Хмельник. Он толково раз'ьясниј присутствующим на митинге о целях и задачах контрреволюционных партий и на примерах показал, как руководители әтих организаций нахо.дили обций язык, чтобы отравлять сознание трудяццихя .

Рабочий фабрики Рабиновича т. Боровский рассказал об ужасах немецкого плена и о трогательной встрече с частями Красной армии. Народ плакал от радости, которую пережил т. Боровский. Т. Боровский в своих выступлениях разоблачил предательскую роль контрреволюционных партий, существовавших в ІІольше. Он заявил, что все эти партии добивались того, чтобы одурачивать народ и лучше держать его в повиновении әксплуататоров. Он призвал население и рабочих не верить контрреволюоионным партиям и идти по пути, указанному коммунистической партией Ленина и Сталина. Собрание бурно аплодировало его фразам.

Кроме агитаторов были посланы для организации и проведения ху.дожественной самодеятельности и выступления перед населением Западной Белоруссии с советскими пьесами, музыкой и художественным населением коллективы артистов и музыкантов, кружки художественной самодеятельности и агитхудожественные брига.ды. Ими охвачены все уездные города и областные центры. Полюжены основы для организации культурно-просветительской работы Западной Белоруссии и организации местных сил артистов, музыкантов и .др.

Союз Советских писателей БССР проводил встречи белорусских писателей с интеллигенцией крупных городов и выделил уполномоченных Союза по объединению писателей Западной Белоруссии в о,дин Союз.

Посланные агитаторы помогали временным управлениям в ра- 
звертывании ряда хозяйственных вопросов. Например, т. Шаврук в Турецкой волости организовал охрану помещичьих имений, провел совеццние с крестьянскими комитетами по вопросу раздела помещичьей земли, организовал снабжение бедняцких хозяйств дровами, наладил работу кооперации и открыл школы. Т. Выгонец, агитатор, работал в Пружанском уезде ${ }^{1}$. Из'ьял 18 человек белогвардейцев, провокаторов и шпионов. Мобилизовал рабочих отремонтировать завод, достал сырье и пустил завод в ход. Обеспечил хлебоснабжение населения.

Хоропоо работали киномеханики Амельяненко и Аладко и шоферы т. Жаворонков и Тонгер. Их автомапины и киноаппаратура работали безотказно. Они своевременно обеспечивали проведение киносеансов .

Т. Фридман мобилизовал крестьян 15 деревень на уборку картофеля на помещичьих землях. Возобновил работу 14 школ в Вязеньской волости. Пустил лесопильный завод и фабрику в м. Илья. Организовал снабжение населения местечек Долгиного и Сморгонь.

Таких примеров можно привести очень много. Имеюоцийся огромный материл о проделанной агитационно-массовой работе должен быть обобцен работниками и описан в книге, которую пишут, о грандиознейших делах напих эюдей, проделанных в Западной Белоруссии.

В заключение нужно отметить о недостатках, которые подмечены агитаторами и которые в будуцем должны быть исправлены.

Т. Вольский в своем отчете пипет: никакого руководства и помоцц со стороны Временного Управления в избирательной кампании по Волковыскому уезду не было. Никто не интересовался состоянием дел на избирательном участке. По окончании работы агитаторов никто не подвел итога агитмассовой работы. В самом В ременном Управлении излишняя суетня, нераспорядительность, неумение разрепгать элементарные вопросы. Грубое и ненужное обращение с посетителями со стороны Юшпе. Т. Вольский пишет: «Только незнанием людей можно об'ьяснить назначение неподходящих работников на такие ответственные участки работы, на какие посланы Юшпе и Калеко».

Агитатор т. Король по Волковыскому уезду пишет: зам. председателя Временного Управления т. Юшпе всю работу по выборам пустил на самотек. Очень груб и нетактичен. Основная его забота это закуіка товаров в магазинах и посылка их домой. 
Об этом же пишет в отчете агитатор т. Каравацкий. На что обращаю Вапе внимание.

Справку составил:

22.XI-39 r.

Инструктор ШК КП(б)Б (podpis) Куров

Oryginal, maszynopis.

Źródło: NARB w Mińsku, zesp. 4, spr. 27, t. 69, k. 323-336.

a Duże litery i podkreślenie słów „tow. Malinowi” oryginału. Pozostałe podkreślenia w oryginale dokonane odręcznie w trakcie czytania.

b Tekst dokumentu zawiera liczne poprawki redakcyjne.

c W następnej linii nieczytelna odręczna poprawka.

1 Wygoniec (por. dok. 19) pisze, że był w pow. postawskim i opisane wydarzenie tam miało miejsce. 